\title{
Educational aspirations and decision- making in a context of poverty. A test of rational choice models in El Salvador
}

\author{
Martina Jakoba (martina.jakob@soz.unibe.ch) \& Benita Combet ${ }^{b}$ (benita.combet@Imu.de) \\ (equal contribution, corresponding author: B. Combet) \\ a Institute of Sociology, University of Bern, Fabrikstrasse 8, 3012 Bern, Switzerland \\ b Institute of Sociology, Ludwig-Maximilians-University, Konradstrasse 6, 80801 Munich, Germany
}

Please cite as follows:

Jakob, Martina; Combet, Benita (2020): Educational aspirations and decision-making in a context of poverty. A test of rational choice models in El Salvador. Research in Social Stratification and Mobility,

https://doi.org/10.1016/i.rssm.2020.100545

Funding: This research did not receive any specific grant from funding agencies in the public, commercial, or notfor-profit sectors.

\section{Competing interests: none}

Acknowledgements: This research was supported by the NGO Consciente, El Salvador. We also want to thank Joël Berger, Sales Hollinger, Hannes Kröger, Alexander Libman, Martin Neugebauer, the participants of the Rational Choice Seminar in Venice, and the reviewers for their helpful feedback.

Version: 11.9.2020 


\begin{abstract}
Previous research on educational aspirations and educational decision-making has mostly focused on high-income countries and thus on a relatively homogeneous socio-economic context. However, educational decision-making may be sensitive to contextual factors such as economic deprivation, a dysfunctional welfare state or poor access to credit markets - characteristics shared by most low- and middle-income countries. To better understand how economically disadvantaged individuals in developing countries make their educational choices, we conducted a survey based on a random sample with high school students in the rural department Morazán in El Salvador, a lower middleincome country in Latin America. Our results show that regardless of the social background, almost all students aspire to pursue tertiary education, probably due to the high tertiary degree premium in earnings and the high social benefits. However, the lack of possibilities to finance their studies generally prevents the realisation of these aspirations for lower social background students. While in high-income countries, cost factors are not very important in the decision-making process, the burden of costs explains around 45 percent of the social background effect in El Salvador. Other factors such as academic confidence, expected future economic benefits, parental status maintenance wish, individual risk aversion and time discounting preferences play only a minor role.
\end{abstract}




\section{Introduction}

Education crucially shapes the course of people's lives, influencing the standards of living they will enjoy, and the positions they will hold within society. Across societies and time, individuals from different socio-economic backgrounds have been consistently observed to differ in their educational choices, with lower-status children opting for less education or less ambitious tracks. Education is thus an important driver in the reproduction of social inequalities. One specific focus of previous research has been to understand the micro-mechanisms behind such class differentials in educational decisionmaking, often by framing educational choices as cost-benefit calculations (e.g. Erikson and Jonsson 1996, Breen and Goldthorpe 1997). While these models have been repeatedly tested in various highincome countries, it remains unclear how the cost-benefit assessment affects educational aspirations and educational choices in a context with widespread economic deprivation, a dysfunctional welfare state and generally poor access to credit markets - characteristics shared by most low- and middleincome countries. Moreover, the overall applicability of these models in a low-income setting remains unclear, since one could also hypothesize that cultural norms and values in more traditional societies prevent underprivileged youth from seriously engaging in rational deliberation regarding the costs and benefits of education. The present study not only provides novel evidence on the importance of the different factors proposed by rational choice models in a context of economic deprivation, but also aims at an evaluation of the explanatory power of these models in such a context. Finally, understanding the main factors that shape educational choices in a particular context is critical for effective policy-making. Hence, this study also offers evidence of crucial value in addressing classbased educational inequality in low- and middle-income countries.

To analyse the mechanisms of educational decision-making in a low-income context, we conducted a survey based on a random sample with high school students in the rural department Morazán in El Salvador, a lower middle-income country in Latin America with a very high social inequality and a considerable proportion of the population living in poverty (e.g. Daude and Robano 2015). Our analytical approach is similar to the strategy used by Stocké (2007) who asked respondents about their subjectively perceived costs, utility, and success chances, in line with the important factors proposed by rational choice models of educational decision-making (e.g. Breen and Goldthorpe 1997). Additionally, we assess respondents' preferences for risk and time discounting according to the extension of the Breen-Goldthorpe model (Breen and Goldthorpe 1997) suggested in Breen et al. (2014). To distinguish whether students act upon different value assessments regarding education or whether their decisions are driven by class-based differences in constraints, we do not only focus on students' final educational plans, but also on their educational aspirations. 


\section{Empirical Context}

\subsection{El Salvador and the Department of Morazán}

Central American El Salvador can be classified as a lower middle-income country. It shares many of the typical characteristics of developing countries like widespread poverty - especially in rural areas -, low levels of educational attainment, low quality of schooling, and the absence of an inclusive welfare state. Besides that, it also suffers from low social mobility, a characteristic shared with many other Latin American countries (Daude and Robano 2015). As Reimers (2001: 61) points out, educational inequality in El Salvador is extraordinarily high: The poorest 40 percent of the population are 3 times less likely to have completed primary education than the wealthiest 10 percent, which is the biggest ratio in Latin America. However, for the current generation of students, primary school enrolment is almost universal and roughly two out of three youth attend secondary school. Tertiary enrolment, in contrast, is still very low with a gross enrolment rate of 28 percent (UIS 2019). Moreover, dropout rates are slightly below $50 \%$ meaning that only about $15 \%$ of young people graduate from tertiary education. With an estimated wage premium of about $230 \%$ associated with a tertiary degree (compared to only $150 \%$ in OECD countries), educational attainment is strongly linked to labour market outcomes (Bashir and Luque, 2012).

The department of Morazán is one of the poorest and most rural regions in El Salvador and is located in the northeastern part of the country. Its 200,000 inhabitants are predominantly children or young adults with $60 \%$ of the population being less than 30 years old. The median household in the region has four members and a monthly income of 277 US Dollar. According to national definitions, $56 \%$ of the population live below the poverty line and $18 \%$ in extreme poverty. ${ }^{1}$ Morazán exhibits particularly low levels of educational attainment. $27 \%$ of adults do not have a primary degree, only $22 \%$ completed secondary school, and merely $5 \%$ possess a tertiary degree. An average adult has only acquired 5.4 years of education; one out of four adults does not know how to read or write (authors' calculations, based on EHPM 2015). ${ }^{2}$

\footnotetext{
${ }^{1}$ According to the authors' calculations. The DIGESTYC (Dirección General de Estadística y Censos, the Salvadoran Department for Statistics) is applying the following definitions: Urban poverty line (daily income per person): approx. 1.80 USD (3.60 USD PPP) for extreme poverty and 3.50 USD (7.20 USD PPP) for moderate poverty). Rural poverty threshold (daily income per person): approx. 1.10 USD (2.30 USD PPP) for extreme poverty and 2.40 USD (4.60 USD PPP) for moderate poverty.

${ }^{2}$ As no statistics are available for Morazán, the numbers in this section are based on the authors' calculations, using the EHPM (Encuesta de Hogares de Propósitos Múltiples) 2015 dataset provided by the DIGESTYC. EHPM is an annually conducted household survey providing representative data on national and departmental level (calculations available upon request).
} 


\subsection{The Educational System in El Salvador}

Figure 1: Educational System in El Salvador (authors' representation according to UNESCO (2012))

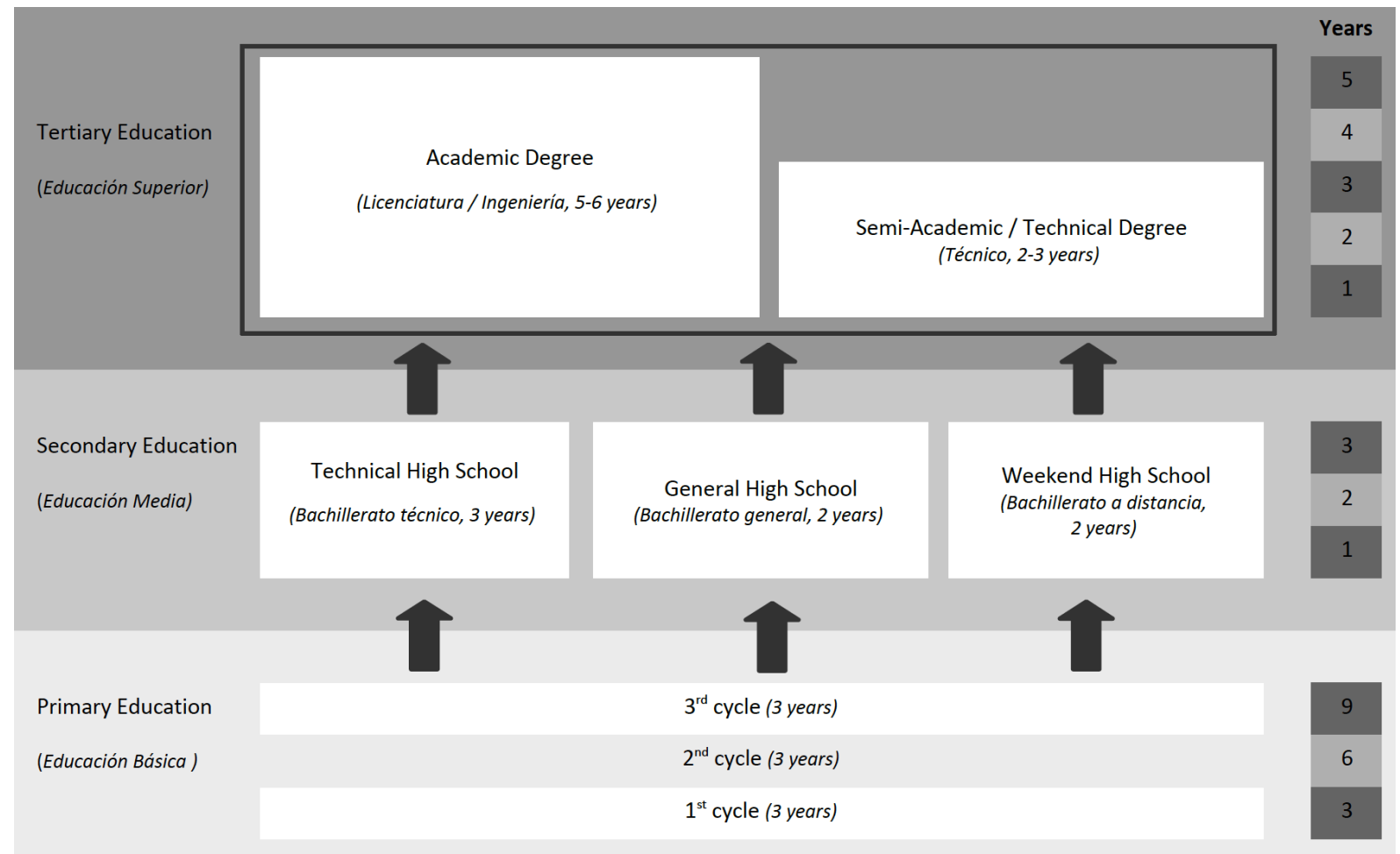

The Salvadoran school system is essentially a one-track system where no ability-based grouping of students takes place (see Figure 1). The first level - primary school-covers the first nine years and is split into three cycles. Regardless of their performance, all primary school graduates can enter secondary education, i.e. high school. There are two types of secondary school programs: general high school and technical high school. The general program is a two-year education in general school subjects while the technical program takes three years and includes additional training in a chosen practical field (e.g. accounting or mechanics). Furthermore, secondary degrees can be completed by attending a "weekend program" that offers classes on Saturdays or Sundays. After graduating from high school, all students are eligible for tertiary education at a technical or an academic university. Technical universities belong to the relatively small semi-academic sector, which offers short-duration careers (2-3 years) while the more numerous academic universities offer longer courses (5-6 years) (Bashir and Luque 2012). ${ }^{3}$ Practically oriented alternatives such as VET (Vocational Education and Training) do not exist (cf. UNESCO 2012). Institutions hosting tertiary education programs are either

\footnotetext{
${ }^{3}$ At a national level, $83 \%$ of the people with a tertiary degree complete an academic or semi-academic career while the remaining $17 \%$ graduate from a non-academic track ("técnico"). The corresponding figures for Morazán are 73 and 27 percent.
} 
private or public. On state-level, $66 \%$ of students enrolled in tertiary education are studying in private institutions (author's calculation based on EHMP 2015 data). ${ }^{4}$ The latter charge monthly fees of at least 70 USD while studying in a public university costs approximately 5 USD a month. Except for applicants of poor municipalities, access to public universities is conditional on the passing of an admission test. ${ }^{5}$ In contrast, private universities normally have no formal admission requirements. While public universities are not generally viewed as lower quality, they tend to be more demanding making dropout or repetition due to insufficient academic performance more likely. For students living in the department of Morazán, the closest tertiary education institutions - one large public university, three private universities and a private technical university - are located in the neighbouring department of San Miguel (indicated average travel time $=2.24$ hours, std. $=1.09$ ).

\section{Theoretical Background}

\subsection{Rational Choice Models of Educational Decision-Making}

In contrast to culturalist approaches (e.g. Bourdieu 1979), which focus on class-based norms and values regarding education, rational choice theories view educational decisions as the result of (at least partially) rational cost-benefit calculations. Building on human capital theory from economics (e.g. Becker 1962) as well as Boudon's theory of the primary and secondary effects of social origin (Boudon 1974) sociological rational choice models (e.g. Erikson and Jonsson 1996, Breen and Goldthorpe 1997) take the educational choices of an individual to depend on three general considerations: (1) the costs, (2) the probability of success and (3) the utility subjects attribute to education or to specific educational careers.

(1) Costs: Following the standard economic model, the costs of education are taken to embrace school-related expenses (direct costs) as well as forgone earnings (indirect costs, opportunity costs). The costs of staying in education or opting for more demanding educational degrees will be experienced as more burdensome or even unaffordable by lower class families. Children from these families will thus tend to drop out of school earlier than their classmates

\footnotetext{
${ }^{4}$ The University of El Salvador (Universidad de El Salvador, UES) is the only public university in the country and operates through four campuses in different regions. Conversely, more than 40 private tertiary institutions in all major cities of the country offer private higher education. For Morazán, $37 \%$ of tertiary education students study at a public university.

${ }^{5}$ In 2016 the University of El Salvador has started to implement a program to increase the enrolment of students from disadvantaged social backgrounds. Residents of the poorest municipalities in the country are exonerated of the admission exam ( $90 \%$ of the students in our sample).
} 
from higher social background. Moreover, individuals may be systematically biased in their assessment of direct costs. In particular, students from lower educational backgrounds may overestimate the costs (or be less confident about the accuracy of their assessment) of further education due to informational barriers as suggested by Erikson and Jonsson (1996). Inaccurately high cost expectations or elevated ambiguity regarding costs would then discourage disadvantaged students from making more ambitious educational choices.

(2) Probability of success: A further determinant of educational decision-making is the expected likelihood for an individual to successfully complete a certain educational career. The beliefs about the probability of educational success in turn depend on a student's ability. Since pupils from a less advantageous socioeconomic background generally exhibit lower levels of academic performance (c.f. primary effects of social origin, Boudon 1974), they should, on average, be less optimistic about their chances to succeed when staying within the educational system or choosing a demanding track. Consequently, they will reach lower educational degrees than their peers from more privileged families. Again, students from lower social backgrounds are often hypothesised to underestimate their ability thereby reinforcing class differentials in educational choices (c.f. Erikson and Jonsson 1996).

(3) Utility: Since education raises people's knowledge and skills, it usually enhances their labour market outcomes leading to higher expected wages. Once again, information barriers may induce a downward bias in the expected wage premium on part of lower-class students, and influence their choices accordingly (e.g. Erikson and Jonsson 1996; Barone et al. 2018). While human capital theory exclusively focuses on these economic benefits, sociological applications consider a further aspect: the "social" utility associated with particular positions within a vertically stratified society. Families are taken to be concerned about the future status of their children and to invest, through education, in more advantageous positions for their offspring. Breen and Goldthorpe (1997) famously argued that this concern plays out differently for different classes - even though families from all socio-economic classes value social status equally. The crucial assumption behind this hypothesis is inspired by prospect theory (Kahneman and Tversky 1979, for an experimental application: Berger and Combet 2017). Parents are taken to exhibit a relative risk aversion regarding the future positions of their children relative to their own positions. Therefore, parents' subjective utility should be more sensitive to status losses than status gains, meaning that they will, above all, try to avoid that their children end up in a social position that is lower than their own. Consequently, when parents' social status is high, longer and more demanding educational careers are required to 
avoid downward mobility. For children from lower social classes, in contrast, less ambitious tracks should already be sufficient to serve the same purpose.

Breen et al. (2014) proposed a further extension of rational choice models of educational decision-making by including two additional psychological factors related to the perceived utility of education: individual time discounting and risk preferences. Time discounting refers to the extent to which individuals discount future benefits when evaluating the present value of a good. This is particularly important for educational choices as the utility people derive from education will accrue in the future. People who attach more weight to future benefits relative to present ones will thus tend to advance further within the educational system. An individual's risk preferences accounts for the fact that an investment in education is an uncertain endeavour. If an educational track is not successfully completed (or if its completion is not rewarded with a better job) one will end up bearing the costs of getting educated without enjoying its benefits. When opting for less education or less demanding tracks, future benefits might be lower but accrue with a higher certainty. People with a stronger risk aversion should therefore exhibit lower educational attainments. Individuals from different social classes might differ systematically in such preferences, which could further reinforce class differentials in educational outcomes. On the one hand, the two factors could mediate the effect of social background, e.g. when high status students are in general more forward-looking and less riskaverse. On the other hand, these preferences might show a heterogeneous effect according to social background, e.g. affecting low status students more strongly, as shown in Breen et al. (2014).

The main concern of research on educational decision-making is with students' final choices. However, these choices can be seen as the realization of aspirations in a given setting of opportunities and constraints. In our framework, aspirations are expected to be mainly driven by ability (operating through success expectations) or by different evaluations of the utility of education. As to the latter, such different evaluations might be caused by relative risk aversion, time discounting or risk aversion preferences, information biases or by class-based norms and values regarding education as assumed by culturalist approaches (e.g., Andrew and Hauser 2010; Bozick et al. 2010; Vaisey 2010). However, cost constraints (or official entry requirements) should not be of much relevance when students consider what they would like to do. For example, if a person is confident enough about successfully completing the career, she can have the aspiration of studying medicine even though she considers the costs to be too high and will therefore not be able to pursue her aspirations. Our definition of aspirations comes thus closer to idealistic than realistic aspirations (Haller 1968). It captures what 
students would like to do after high school if anything (including entering university) was possible but does not presuppose successful completion.

To sum it up, sociological rational choice models of educational decision-making try to understand individual aspirations and choices in education as the result of a cost-benefit analysis. Hence, they predict a direct effect of the different cost-benefit variables on educational outcomes. Moreover, they also aim at accounting for class differentials in educational outcomes. These differentials are taken to be driven by differences in the perceived costs and benefits of education, i.e. by mediation effects. Finally, for some of the cost-benefit variables heterogeneous effects are assumed, meaning that these factors play out differently depending on an individual's social status.

\subsection{Previous research results}

To test rational choice models of educational decision-making, two types of approaches have been pursued: On the one hand, the models have been tested indirectly. Authors have used indirect measures like family income or number of siblings for subjectively expected costs of education, test scores for the perceived probabilities of success and nonlinearities in social status effects for relative risk aversion (e.g. Davies et al. 2002). On the other hand, some studies have tried to test more directly whether educational choices can be seen as the product of the proposed subjective cost-benefit evaluation, by asking the subjects about their personal assessment of these factors. In this article, we will focus on the latter approach.

The most comprehensive test of subjective cost-benefit evaluations was conducted by Stocké (2007) and Barone and colleagues (2018). They asked parents (Stocké 2007) or students (Barone et al. 2018) about their subjective assessment of direct and indirect costs, success probability, and the importance of status maintenance. Other studies also used this method assessing only a subset of the proposed factors. Concerning perceived costs, results seem to depend on the stage within the educational career. While costs were important predictors for tertiary enrolment in the research by Schindler and Reimer (2011) and Barone et al. (2018) ${ }^{6}$, findings are less clear for lower secondary education with Becker (2003) finding positive effects and Stocké (2007) finding none. Success probability as well as general utility was found to be an important factor in all studies that explicitly tested it (Barone et al. 2018, Becker 2003, Gabay-Egozi et al. 2010, Stocké 2007, Tolsma et al. 2010).

\footnotetext{
${ }^{6}$ Schindler and Reimer (2011) had to operationalize the perceived costs with a rather imprecise measure on students' preference for financial independence from their family, while Barone and colleagues (2018) were able to test the importance of both direct and indirect costs with the latter having a larger impact.
} 
Results concerning relative risk aversion are mixed: While Barone et al. (2018), Becker (2003) and van de Werfhorst and Hofstede (2007) found an effect, Stocké (2007) and Gabay-Egozi et al. (2010) did not. Barone et al. (2018) also examined the role of information biases and found that students with less educated parents estimate the returns to education and the expected wages to be lower and the difficulty of university classes to be higher than students from more privileged backgrounds. Finally, results on whether the explanatory factors of the rational choice models mediated the social background effects are mixed. While in Stocké (2007) the rational choice factors did not mediate the effect of social background, costs were found to play a role in other studies focusing only on this factor: In Barone et al. (2018), the perceived burden of indirect costs explained around 15 percent of the total social background effect, while the importance of financial independence explained around 10 percent in Schindler and Reimer (2010).

Not only educational decision-making, but also educational aspirations show large social class disparities, as findings for many high-income countries confirm (e.g., Buchmann and Dalton 2002). However, the evidence is less clear on the formation of aspirations. While several studies show that aspirational differences evolve early in the educational career and are largely persistent (e.g., Andrew and Hauser 2010), others argue that initially small difference grow larger as low-status students lower their aspirations over time (e.g., Bozick et al. 2010), or that students from different backgrounds adjust their aspirations flexibly in response to their (diverging) performance (e.g., Morgan 2005).

In the context of low- and middle-income countries, the research on factors influencing educational decision-making has been scarce so far, and only few studies have come close to analysing possible underlying mechanisms. These have mostly focused on the role of cost-based factors, i.e. on family income, educational expenses, or sibship size, with all of them being very strong predictors for educational attainment (for Latin America: Murakami and Bloom 2008, Bashir and Luque 2012, globally: e.g. Filmer and Pritchett 1999). By means of randomized controlled trials, researchers also assessed the role of the reduction of direct costs with conditional cash transfers (e.g. Schultz 2004, Baez and Camacho 2011, Mo et al. 2013) and the reduction of burden of direct costs with unconditional cash transfers (e.g. Kilburn et al. 2017), concluding that these policies increase enrolment rates and reduce dropout rates. In contrast, there is no available evidence on the influence of individually perceived success probability. ${ }^{7}$ Interestingly, researchers have also neglected utility-based choice

\footnotetext{
${ }^{7}$ While the effect of class-based success expectations has not directly been studied, the existence of primary effects of social origin have been repeatedly reported for lower and middle-income countries in general and also for different Latin American countries (Rosenblum 2009, World Bank 2018). Explanations regarding these effects primarily refer to the consequences of economic deprivation experienced by low-status children in these countries (e.g. chronic malnutrition, exposure to infectious diseases, chaotic and often violent living environment).
} 
mechanisms, despite the extraordinarily high economic returns to tertiary education in many middleincome countries. Notable exceptions are two randomized controlled trials who provided students with information about returns to education, finding no effects (Loyalka et al. 2013) or positive effects (Nguyen 2008).

Overall, the evidence for high-income suggests that while costs-benefit evaluations do affect educational choices, the explanatory power of rational choice models is limited, leaving much room for complementary or competing approaches focusing on factors such as social norms or cultural capital. As to low- and middle-income settings, the evidence base is very thin and the mechanisms behind educational disparities in a context governed by poverty are poorly understood.

\subsection{Predictions of rational choice models in low- and middle-income contexts}

There are many theoretical reasons to believe that the cost-benefit factors could affect individuals in low- and middle-income countries differently due to contextual characteristics such as economic deprivation, the absence of an inclusive welfare state, poor access to credit markets, job allocation through social networks and the low quality of education.

First of all, the costs of education might play a more fundamental role in low- and middleincome countries, where underprivileged students usually do not receive financial support and access to the credit market is difficult for the poor (Torche and Spilermann 2008). On the one hand, the additional costs for transport to the university or the fees of the university themselves may pose a heavy burden on poor households or be simply unaffordable for them. ${ }^{8}$ On the other hand, child or youth labour is often an additional income source necessary for survival, meaning that the opportunity costs of tertiary education may be more relevant. The families of low status students may thus have to cut on basic expenses to be able to pay for university, and survive yet more years without further contributions to the household income. Moreover, class-based biases regarding the costs of education can be expected to be more pronounced in less developed societies with a more limited flow of information than in a high-income context. We would thus expect cost assessments to be more important in determining educational decisions and in accounting for class-differentials in these decisions than in high-income countries.

\footnotetext{
${ }^{8}$ This is exacerbated by the well-documented fact that credit markets in developing countries fail to provide affordable loans to the poor (c.f. Banerjee 2003).
} 
Whether the individually assessed success probability plays out differently in low- and middleincome countries is less clear. As in many developing countries, in El Salvador, certificates are more or less purchasable at private universities. At public universities, the standards are higher and students fail courses more often, but they are allowed to repeat them several times. Consequently, students usually drop out only if they cannot afford tuition anymore. We would therefore expect that a higher academic ability and a positive assessment thereof must be more important for students with less financial means who expect to attend a public university and do not have the means to prolong their university career over a longer time. This may be further reinforced by inaccurately low levels of confidence among low-status students regarding their success probability, which can be expected to be particularly strong in a context where information regarding academic requirements does not flow easily to poor rural villages.

In general, the utility of tertiary education is imminent when considering the premium in annual earnings of around $230 \%$ Salvadoran students are estimated to obtain for tertiary education completion (compared to 150\% for OECD countries, Bashir and Luque 2012). Furthermore, the high demand for academic professionals may go hand in hand with a high perceived prestige attributed to university degrees (or professions requiring them). We would therefore expect educational aspirations to be high across all status groups, particularly among individuals who expect high economic and social benefits. Again, it is plausible to assume particularly pronounced class-specific biases (or uncertainties) in utility assessments, since information on labour market perspectives for university graduates is not easily accessible and often flows though social networks disadvantaged students may lack. Concerning parental motivation for status maintenance, we do not expect the mechanism to differ from highincome countries: Higher social background students are probably more affected by status maintenance wishes than lower social background students attending high school as they have already surpassed their parents' educational degree and are not very likely to end up even below their parents' low-prestige jobs in domestic services or agriculture.

Psychological factors influencing the perceived utility of pursuing tertiary education, i.e. individuals' risk aversion and time discounting preferences, might affect people differently in lowerand middle-income countries too. Concerning risk aversion, we expect it to play a more crucial role in low- and middle-income countries. Failures to complete a career due to unforeseen economic shocks should be much more likely and a loss of invested resources far more consequential in a country context heavily affected by poverty. If studying becomes more risky, particularly for lower social background students, risk-averse individuals should be more likely to be deterred from it. Concerning time discounting preferences, our prediction deviates from Breen et al.'s (2014) result that all social classes react equally to time discounting preferences. In our context, we expect lower social 
background students' educational aspirations and choices to be particularly sensitive to time discounting preferences. When low status equals extreme poverty, individuals may experience limited "bandwidth" making them focus more strongly on immediate problems at the expense of future benefits, as discussed in Shah et al. (2012).

Given the huge benefit of tertiary education on the one hand, the imminent hurdles of pursuing it on the other, we will not only focus on the final educational decision, but also take into account students' aspirations. We expect that most students aspire to complete tertiary education due to the high skill premium in annual earnings with somewhat lower rates for low-status students due to a less favourable self-assessments of their abilities and informational biases. However, the high costs of education combined with the lack of institutions providing affordable loans or scholarships should prevent many students from realizing these aspirations thereby reinforcing the social background disparities in educational decision-making.

Finally, one can also question the overall suitability of rational choice models in explaining educational disparities in a setting of poverty. On the one hand, one could argue that due to the high (relative) costs and potential gains, individuals in a context of poverty may be more prone to engage in careful rational deliberation. On the other hand, one could also suspect educational choices in poorer and more traditional societies to be more strongly driven by social norms and values rather than rational calculations. For children from poor and remote villages where most people are farmers or housewives and traditional values prevail, tertiary education may just not be a natural option to consider. It is thus not a priori clear if rational choice models are well equipped to explain educational disparities in low- and middle-income settings, or if culturalist approaches might be more appropriate. 


\begin{tabular}{|c|c|c|c|c|}
\hline Concept & Measure(s) & Direct effect & $\begin{array}{l}\text { Mediation of soc. } \\
\text { background } \\
\text { effect }\end{array}$ & $\begin{array}{l}\text { Effect } \\
\text { hetero- } \\
\text { geneity }\end{array}$ \\
\hline \multicolumn{5}{|l|}{ Costs } \\
\hline $\begin{array}{l}\text { Direct costs } \\
\text { (absolute) }\end{array}$ & Estimated monthly costs & $\downarrow$ study plans & $\underline{\text { Yes }}$ & \\
\hline $\begin{array}{l}\text { Indirect costs } \\
\text { (absolute) }\end{array}$ & Estimated forgone earnings & $\underline{\downarrow}$ study plans & $\underline{\text { Yes }}$ & \\
\hline $\begin{array}{l}\text { Burden of direct } \\
\text { costs (relative) }\end{array}$ & $\begin{array}{l}\text { Affordability/Perceived cost } \\
\text { burden for family }\end{array}$ & $\underline{\downarrow}$ study plans & $\underline{\text { Yes }}$ & \\
\hline $\begin{array}{l}\text { Burden of indirect } \\
\text { costs (relative) }\end{array}$ & $\begin{array}{l}\text { Perceived burden of forgone } \\
\text { earnings for family }\end{array}$ & $\underline{\downarrow \text { study plans }}$ & $\underline{\text { Yes }}$ & \\
\hline \multicolumn{5}{|l|}{ Success Probability } \\
\hline $\begin{array}{l}\text { Objective success } \\
\text { probability }\end{array}$ & Grades & $\begin{array}{l}\text { 个 study aspirations } \\
\uparrow \text { study plans }\end{array}$ & Yes & $\underline{\text { Yes }}$ \\
\hline $\begin{array}{l}\text { Subjective success } \\
\text { probability }\end{array}$ & $\begin{array}{l}\text { Confidence to successfully } \\
\text { complete university }\end{array}$ & $\begin{array}{l}\uparrow \text { study aspirations } \\
\uparrow \text { study plans }\end{array}$ & Yes & $\underline{\text { Yes }}$ \\
\hline \multicolumn{5}{|l|}{ Benefits } \\
\hline Economic benefits & Perceived wage premium & $\frac{\uparrow \text { study aspirations }}{\uparrow \text { study plans }}$ & $\underline{\text { Yes }}$ & \\
\hline Social benefits & $\begin{array}{l}\text { Importance of education to } \\
\text { be "someone" in life }\end{array}$ & $\frac{\uparrow \text { study aspirations }}{\uparrow \text { study plans }}$ & $\underline{\text { Yes }}$ & \\
\hline Relative risk aversion & $\begin{array}{l}\text { Importance of status } \\
\text { maintenance for parents }\end{array}$ & $\begin{array}{l}\downarrow \text { study aspirations } \\
\downarrow \text { study plans }\end{array}$ & & Yes \\
\hline $\begin{array}{l}\text { Individual risk } \\
\text { aversion }\end{array}$ & Real choice measure & $\frac{\downarrow \text { study aspirations }}{\downarrow \text { study plans }}$ & $\underline{\text { Yes }}$ & $\underline{\text { Yes }}$ \\
\hline Time discounting & Real choice measure & 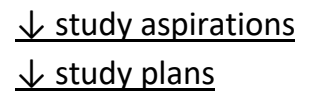 & $\underline{\text { Yes }}$ & $\underline{\text { Yes }}$ \\
\hline
\end{tabular}

Note: Underlined if we expect a particular strong effect in a low income setting

\section{Analytical strategy}


In coordination with the NGO Consciente in El Salvador and the Salvadoran Ministry of Education (MINED), a survey with 450 high school students in their final year ${ }^{9}$ in the department of Morazán ${ }^{10}$ was conducted. ${ }^{11}$ The 20 classes from 15 schools were selected randomly from a list previously obtained from MINED. To enhance the efficiency of estimations, a stratified sample was drawn. Geographical location (North, Centre, and South) and secondary school track (general, technical, and weekend high school) were used as stratifying variables. ${ }^{12}$ In the selected classes, a questionnaire was administered to all students present at the time of data collection (overall student absenteeism of about $8 \%$ resulted in a response rate of $92 \%) .{ }^{13}$ Our final sample consists of the 445 to 448 students who had no missing values on our two dependent variables (all missing values on the independent variables have been imputed).

\subsection{Operationalisation and variables}

\footnotetext{
${ }^{9}$ At the time point of data collection (October 2017), students already had to register to attend public university, but they do not know whether they will be admitted, while for private universities later registration is possible. While it might be the case that some students are still indecisive about their study plans, less than one percent $(\mathrm{N}=2)$ did not answer the question.

${ }^{10}$ Note that while Morazán is not representative for the country as a whole, the setting exhibits the typical characteristics of a low-income region with widespread poverty, low levels of educational attainment and a sizable share of people employed in agriculture. Clearly, a more comprehensive assessment covering El Salvador as a whole or even several developing countries would have been highly desirable. However, data collection in developing regions is associated with great challenges such as the low quality of administrative data, security problems or poor transportation infrastructure. Since these problems intensify sharply with increasing geographical coverage, we decided to confine our analyses to one department. We think there is much to learn from our data from Morazán and we hope that future research will provide further insights into the external validity of our findings.

${ }^{11}$ Obviously, at this stage of the educational career, we deal with a selective sample of students since a sizable fraction of (predominantly lower background) students drops out before completing high school (see section 2). This implies that the remaining students from poorer backgrounds may be atypical for youth of their social standing. For example, we find that students of parents with no educational degree assess themselves as more hardworking than students who have parents with a tertiary degree $(p=0.003)$. Further, since Salvadoran high schools are also open to older students who want to resume schooling, our age range is from 16 to 37 with an average of roughly 18 years, depending on the high school track.

${ }^{12}$ Both variables are expected to be strongly related to decisions regarding tertiary education. Geographical location was used because universities are closer and thus more accessible for those living in the south of the department. School track was assumed to play an important role because the general high school ( 2 years) is a more direct path to university than its technical counterpart (3 years). Additionally, the weekend-based high school is usually preferred by those already in the labor market, who may also be less inclined to enroll in tertiary studies. Furthermore, the variables are also expected to be related to other important characteristics such as poverty, urbanization, and ability. In our main estimation models, we control for geographical location but not for high school track, since the choice of these tracks may represent an anticipation of the university aspirations we aim to explain. However, we also conduct within-track analyses as a robustness check, which leaves our findings largely unchanged (results are available at the GESIS repository).

${ }^{13}$ Since none of the selected classes refused to participate in the study, attrition is only due to student absenteeism on the day the survey was conducted. While there are good reasons to believe that absenteeism is not completely random as, for example, less motivated or poorer students may be more likely to miss a class, a potential bias introduced by selective attrition is likely to be small.
} 
Survey questions are inspired by previous theoretical and empirical research in the field particularly by the Breen-Goldthorpe model and its test by Stocké (2007) - and adapted to the Salvadoran context. Furthermore, a pre-test with two high school classes was conducted and several questions were modified accordingly. At the end of the survey, participants were confronted with two real choice situations about time discounting and risk preferences respectively. In all models, we control for respondents' age, gender, whether they already have children (and an interaction between gender and being a parent), whether they live in a municipality with entrance examinations, and for the location (North, Center, South) and the degree of urbanization of their place of residence. The exact operationalization and the descriptive statistics (weighted with the design weights) are presented in Table A1 in the Appendix.

The dependent variables in this study are based on students' self-reported educational perspectives after high school. Broadly speaking, high school graduates from Morazán are confronted with a binary choice situation: They can enter a tertiary education institution (a technical or an academic university) ${ }^{14}$, or they can leave the educational system (and enter the labour market, do domestic work, or migrate). ${ }^{15}$ Based on that, two different concepts are analysed as dependent variables: (1) students' study aspirations ("What would you like to do after high school?"), and (2) students' study plans ("What will you do after high school?"). As we were not able to measure students' actual transition and only their plans, our results represent a conservative estimate of the final choice. To get a broader perspective on students' aspirations and plans, we also assessed their occupational wishes ("What occupations would you like to have?") and expectations ("What occupation do you think you will have?").

To assess students' social backgrounds, two different measures are used: The first measure represents the highest educational degree completed by the students' parents. When parents differed in their educational attainments, the degree of the more educated parent was taken. ${ }^{16}$ The second

\footnotetext{
${ }^{14}$ Unfortunately, it is not possible to distinguish between the choices for an academic versus a technical university as only a minority of around 8 percent of our respondents wishes or plans to attend a technical university (while $67 \%$ wish and $37 \%$ plan to attend a general university).

${ }^{15}$ Respondents were also asked directly, if they wished and planned to study after high school ("Would you like to study after high school?"; "Will you study after high school?"). Overall, this measurement strategy yields higher estimates for both aspirations ( $92 \%$ vs. $75 \%$ ) and plans ( $51 \%$ vs. $44 \%$ ), possibly because the wording of this question did not compel students to evaluate studying against other options, thereby inducing them to take a long-term perspective instead of reporting their most immediate plans and wishes. We also conducted all analyses with these alternative dependent variables and the main results do not differ (results are available at the GESIS repository).

${ }^{16}$ This was the degree of the mother in $35 \%$ of the cases and the degree of the father in $12 \%$ of the cases. In the remaining $53 \%$ of the cases, both parents had identical educational attainments. The reason for that pattern is not that mothers are generally more educated than fathers, but rather that in $23 \%$ of the cases, respondents were unable to report their father's educational degree in the first place. In our sample, only half of the youth live with their fathers - many of them do not even know them. As it might be that father absenteeism affects
} 
measure is an indicator for social class. In contrast to high-income countries, the economic system in El Salvador is heavily based on non-wage labour sources (such as subsistence farming, selfemployment, and remittances, c.f. Lanjouw 2001). The social class categories from high-income countries are thus not applicable to the specific situation in less developed countries. We therefore decided to create a social class index based on a ranking of occupations similar to prestige scales. ${ }^{17}$ The measures of educational background and social class are highly correlated (Spearman's Rho: 0.68, $p<$ $0.001) .{ }^{18}$ It is necessary to binarise the social background variables for certain analyses. For parental education, we differentiate between those students whose parents have an educational degree versus those whose parents did not finish school (39\% vs. $61 \%)$. For the social class variable, we split the distribution at the median (lower social class $\leq$ median value).

A considerable number of theory-driven variables related to perceived costs, success probabilities and benefits of education were used for this study. The operationalisation strategy for these variables roughly follows Stocké's (2007) approach, but adaptations of questions to the local context were undertaken and further questions were added.

We use five different cost-related variables. To assess direct costs (absolute) of education, students were asked to estimate their monthly expenditures in case they start a tertiary education. Indirect costs (absolute) of education are represented through a measure of forgone earnings. Students were asked about the probability to find a job after finishing high school and about their estimated earnings in a potential job. Forgone earnings were then computed as the product of subjectively assessed employment probabilities and expected salaries. ${ }^{19}$ The remaining variables represent the relative burden of direct and indirect costs respectively. The burden of direct costs was

respondent's decision-making, we controlled for absent fathers in additional robustness checks (results are available at the GESIS repository). This does not change our results.

${ }^{17}$ Eight El Salvadorian coders ranked all parental occupations on a scale from 1 (low) to 3 (high status). Typical low status jobs are farmers (subsistence or employed, average rating $=1.09$ ) or housewives (average rating $=$ 1.02), among medium status jobs are electricians (average rating $=2.05$ ) or bricklayers (average rating $=1.82$ ), while high status jobs are teachers (average rating $=2.56$ ) or doctors (average rating $=2.875$ ). The inter-rater consistency was $62 \%$ for fathers' and $81 \%$ for mothers' occupation, which can be taken to reflect the lack of standardization in the occupation system. We thus decided to create a metric variable based on the average rating of all coders for both parents. As robustness check, we also tested whether a categorical variable based on the parent with the higher rating leads to different results, which is not the case (results are available at the GESIS repository).

${ }^{18}$ Both social background measures are strongly correlated with an index of family wealth (c.f. Traynor and Raykov 2013) based the available items and facilities in a household (parents' educational degree: $0.57, p<0.001$; parents' occupational prestige score: $0.56, p<0.001$ ), further corroborating the validity of these status measures. ${ }^{19}$ As people in El Salvador are generally not familiar with probabilities, participants were not asked to report numeric probabilities. Instead, they had to answer on a language-based six-point-scale (1=impossible, [...], $6=$ completely certain). To obtain probabilities, the answers on this scale were then linearly transformed into numeric values between 0 and 1 . Note that this procedure only provides an approximation of the true subjective probabilities as perceived by the students. 
measured by asking respondents first how difficult the financing of tertiary education would be for their families. Since tertiary education may not only be more burdensome, but simply unaffordable for some families, we included a second binary variable where students had to indicate if their families have the means to finance their studies or not. As an indicator for burden of indirect costs, the students were asked whether their parents wanted them to work as soon as possible in order to contribute to the family's income.

To assess success probabilities, students' most recent grades were used as an objective measure. Since grades are hardly comparable across school classes and high school tracks (general vs. technical), they were standardised within school classes. ${ }^{20}$ For the subjective measure, we relied on students' academic confidence, which was measured on a 6-point-scale, where students had to indicate whether they believed to have the qualities necessary for the successful completion of an academic career. ${ }^{21}$

We operationalised the benefit-related variables through several subjective measures. To assess economic benefits of education, the expected returns to education were computed. They are calculated as the difference in expected earnings (employment probability multiplied by expected salary) between a high school and a tertiary degree. Social benefits, i.e. benefits in terms of status attainment, were measured by asking students how important they believed education to be in order to gain a prestigious position in society (phrased as "becoming someone in life"). The status maintenance wish of students' parents was assessed with a question on how much it would bother their parents if they ended up in a less prestigious position than theirs. ${ }^{22}$ The variables representing time discounting and risk preferences were measured through two real choice situations. The first situation was designed to assess time discounting preferences. Respondents were informed that all survey participants would enter a lottery with one winner. In case they won, they would either (i)

\footnotetext{
${ }^{20}$ Note that the resulting variable is still a rather poor representation of students' academic abilities. It captures how well students fare relative to their classmates, but neglects differences in abilities between school classes. Unfortunately, the available data does not contain reliable information that would allow such an interschool comparison.

${ }^{21}$ One could correctly argue that this measure does not reflect students' self-perceived success chances, but their self-confidence. In the case of the education system in El Salvador, the lack of standardization between schools prohibits an informed assessment of respondents' own skills and thus their success chances. Consequentially, students' self-confidence correlates highly with their perceived success chances.

${ }^{22}$ Note that according to our theoretical reasoning, low- and high-status students should not differ on this variable and, consequently, we do not expect a mediation effect. However, status maintenances should have a stronger impact on educational choices for high-status students, meaning that we do expect effect heterogeneity. An alternative approach to analyzing the role of RRA proposed, among others, by Stocké (2007) is to ask student how important they consider a tertiary degree for status maintenance. While the answers to such a question should indeed be stratified by social class, we did not include it into our questionnaire due to endogeneity concerns: Even if students were not motivated by status maintenance, their answers to this question should be (almost by definition) highly correlated with their socioeconomic background and, thereby, predictive for their educational choices. Hence, we decided to analyze the role of RRA by exploring effect heterogeneity.
} 
receive 10 US Dollar immediately or (ii) 100 US Dollars (around 1/3 of an average monthly income) one year later. ${ }^{23}$ Subsequently, participants had to indicate their preferred choice. When data collection was completed, the winner was determined by chance and contacted through a phone call. Risk aversion was measured in a similar way. At the end of the survey, all students were told that they would receive a small gift for their participation. According to their choice, they either (i) received a candy or (ii) participated in a lottery for twelve candies with success chances of one third. Winners were either determined by the online tool or by a lottery and candies were distributed as soon as all students in a class had completed the survey.

\subsection{Methods and analytical approach}

Our analyses are based on the following methods ${ }^{24}$ : To identify the direct effects of the social background and the cost-benefit variables on study aspirations and plans, logistic regression models are estimated. Effect sizes are presented as marginal effects (AME), or, for dichotomous variables, as discrete change effects (DCE). For the estimation of the mediation effects, i.e. whether cost-benefit variables can account for social background differentials in educational outcomes, we apply two decomposition methods. First, we use the KHB method, which offers an elegant solution to the rescaling bias and thus enables us to compare coefficients from nested nonlinear probability models (Karlson et al. 2011, Kohler et al. 2011). Second, the two-fold Blinder-Oaxaca decomposition further allows us to decompose the total effect of a dichotomous variable in a linear regression into an unexplained "direct" effect and the explained "indirect" effects of different variables (Jann, 2008, Oaxaca and Ransom, 1994). We apply a weighting method proposed by Yun (2004) to account for the non-linear relationship between the dependent and the independent variables. Effect heterogeneity, i.e. whether some factors play out differently depending on social status, is analysed through interactions in our logit models between the variable of interest and our social background measures and presented graphically. Differences are calculated with bootstrap (250 replications). The survey design, i.e. weights, clusters and strata, is taken into account in all analyses. Consequentially the

\footnotetext{
${ }^{23}$ One could argue that in countries with poorly functioning institutions, this experiment would not be able to differentiate between students' generalized trust and their time discounting preferences. However, when we asked students about the reasons for their choice in our pretest, no one mentioned a lack of trust. Rather, they all stated that they urgently needed the money.

${ }^{24}$ The Stata scripts (Version Stata 15.1) are available at the GESIS repository. Additional user-written packages that were used are: coefplot (Jann 2014), estout (Jann 2007a), fre (Jann 2007b), grc1leg (by Vince Wiggins), grstyle (Jann 2018a, Jann 2018b), kappaetc (Klein 2018), khb (Kohler et al. 2011), mimrgns (Klein 2014), and oaxaca (Jann 2008).
} 
standard errors are robust for the complex data structure. All multivariable analyses are based on multiple imputation with chained equation (30 imputations). ${ }^{25}$

Our analytical strategy is a follows: As a start, we take a look at the broad picture presenting evidence on the extent of social-background effects on educational decision-making and occupational plans. In a next step, we assess the explanatory power of the cost benefit-variables on these educational inequalities. We first use the KHB method to establish whether adding the cost-benefit variables significantly decreases the social background effect. Second, estimates of the Blinder-Oaxaca decomposition tell us the overall explanatory power of the rational choice factors in our study setting. Following, we analyse the process of (class-based) educational decision-making in more detail by looking separately at the different cost-benefit variables. Using the results from the logistic regressions and the Blinder-Oaxaca decomposition, the role of each factor in accounting for (1) individual (direct effects) as well as (2) class-based differences in educational decision-making (mediation effects) is explored. Based on our theoretical reasoning, (3) we further examine the influence of some of the cost-benefit factors to depend on socio-economic status (heterogeneous effects) with interaction models.

\section{Results}

We start the discussion of our results by describing the extent of educational inequality in decision-making in Morazán. Figure 2 presents the study aspirations and plans by social background. In line with our reasoning, we observe a very high overall study motivation among all students. Regardless of their parents' education or social class, almost all students would like to continue with tertiary education, a surprising result in light of previous research overwhelmingly showing social class disparities in aspirations. In contrast, students' actual study plans are highly sensitive to their parents' education and social class. While for high status students' educational aspirations and educational plans roughly boil down to the same thing, a huge gap between wishes and actual intentions appears for those from less advantaged households. For example, for about half of students from lower social classes, study aspirations do not translate into study plans.

\footnotetext{
${ }^{25}$ The variables with the highest number of missing answers were parental educational degree ( $N=24,5 \%$ of our sample), perceived direct costs $(\mathrm{N}=11,2.5 \%)$, and perceived economic benefits $(\mathrm{N}=9,2 \%)$. As robustness check, we also conducted all analyses without the imputed data, which does not change the results (results are available at the GESIS repository).
} 
Figure 2: Study Aspirations and Plans by social background
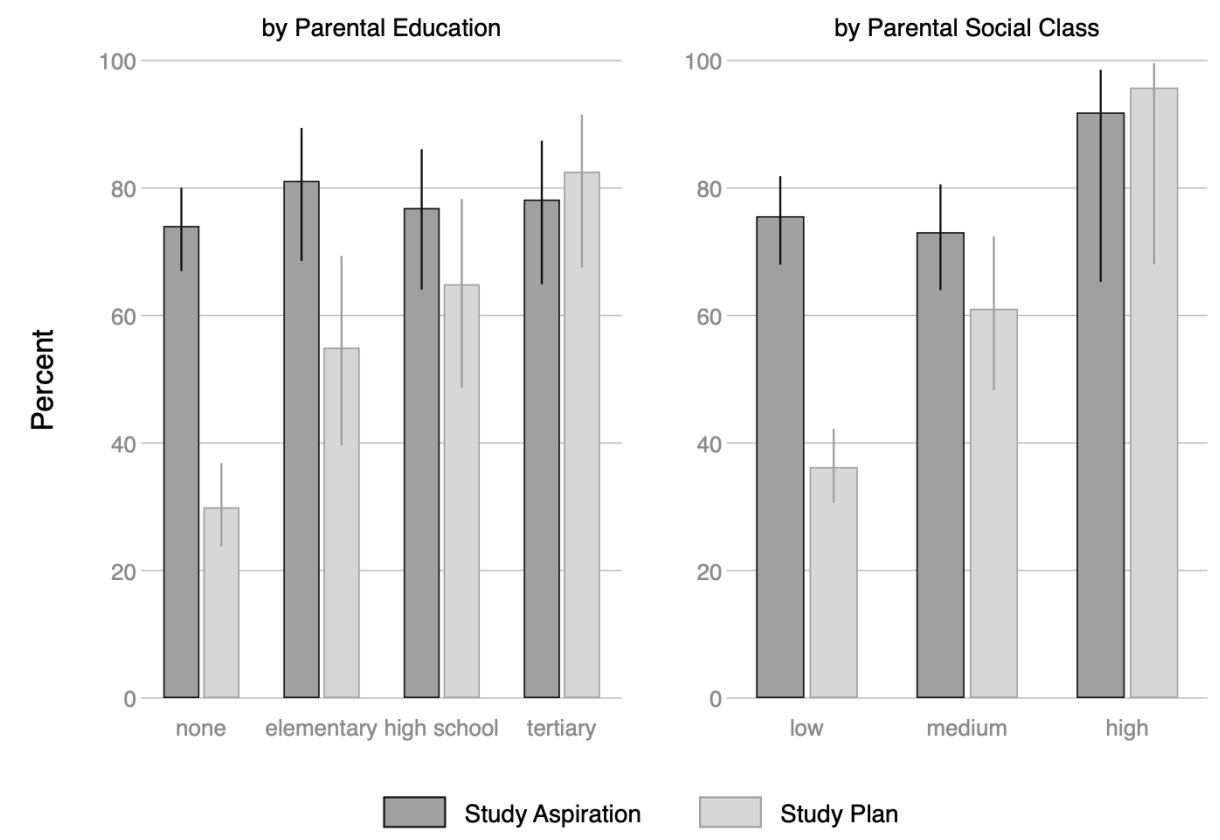

To put these educational patterns into context, it is informative to take a brief look at students' occupational aspirations and plans. A similar picture emerges (see Figure 3): Regardless of students' social background, almost all of them dream of high-status jobs such as doctors (15\%), teachers (14\%), and engineers (13\%), even though most of their parents worked in low-status jobs. However, while well-off students often expect to make it to their preferred high-status professions, less advantaged students usually do not count on their occupational wish becoming reality and are more likely to think they will end up in low-status jobs such as domestic services (10\%) and farming (4\%). ${ }^{26}$ Tertiary education is clearly perceived as a means of attaining social status. Students who plan to study after high school expect to end up in occupations associated with higher status (bivariate regression, difference in occupational prestige points $=0.66, p<0.001$ ).

\footnotetext{
${ }^{26}$ Additional bivariate regression analyses show that the occupational status of the desired job does not differ between social background $(b=0.017, p=0.502)$, while higher social background students' likely occupation is 0.36 prestige points higher than that of lower social background students $(p=0.001)$. Regardless of social class, likely occupations tend to be of lower status than desired occupations, although the difference in prestige points is much larger for lower social background students $(b=-0.34, p=0.001)$.
} 
Figure 3: Distribution of occupational prestige score

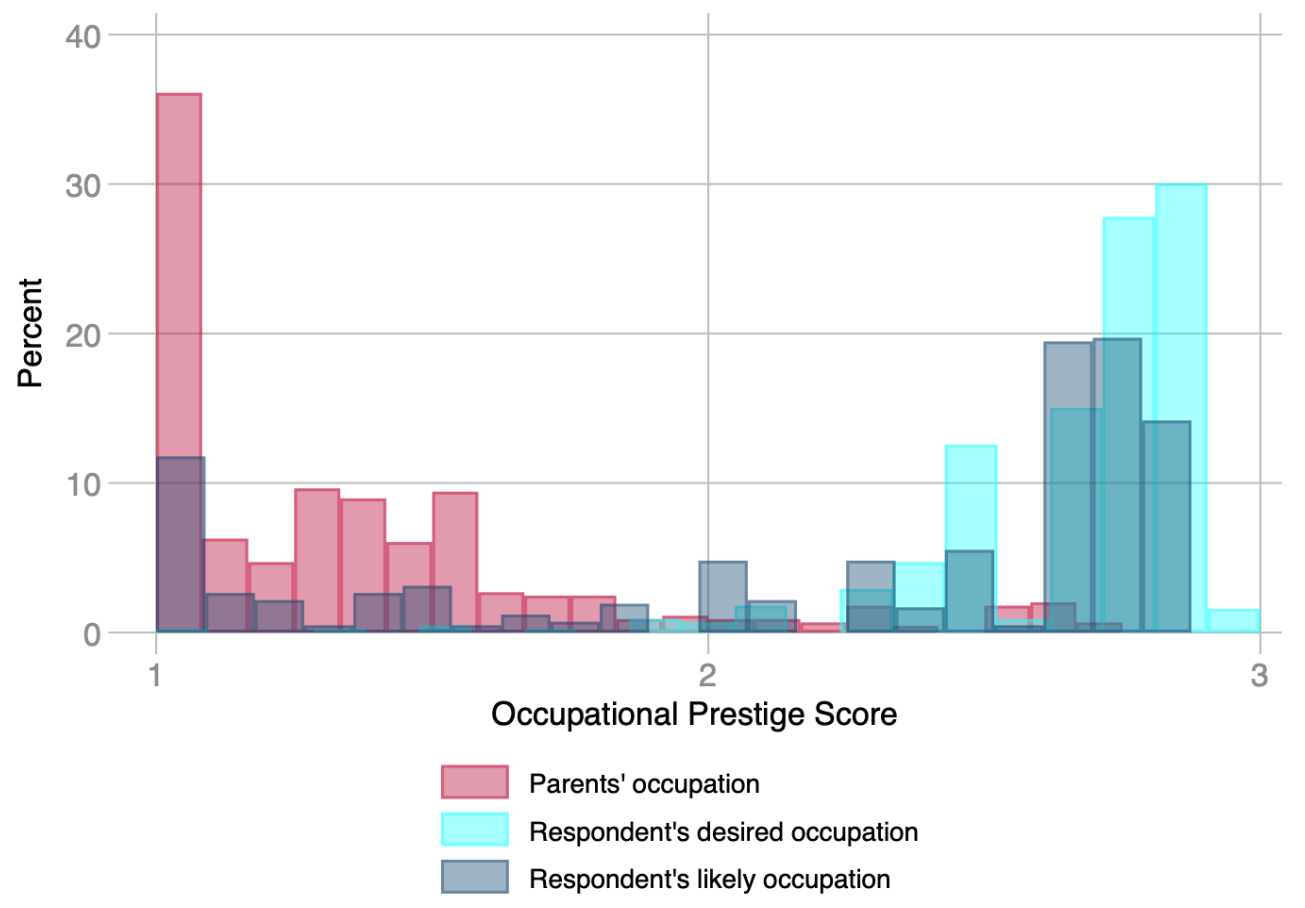

Notes:

Parents' occupation: mean $=1.36$, std. $=0.41$.

Respondent's desired occupation: mean $=2.67$, std. $=0.25$.

Respondent's likely occupation: mean $=2.24$, std. $=0.66$.

Most often mentioned occupations: Father: Peasant (44\%), bricklayer (16\%), salesperson (11\%). Mother:

Domestic service $(67 \%)$, salesperson (15\%), teacher (5\%)

Let us now turn back to the educational mechanisms we set out to analyse in this study. The multivariable analyses in Table 2 confirm the findings from the bivariate results in Figure 2: Students' study aspirations are not significantly influenced by parental education or social class (Model A1), while students' study plans clearly are (Model B1). In a next step, we examine whether these social background effects in Model B1 can be explained by class-specific cost, success and utility considerations. ${ }^{27}$ As the Model B5 shows, the cost-benefit variables indeed mediate the social background effects to a large extent. In particular, the initially strong effect of having parents with

\footnotetext{
27 In Table A2 in the appendix, we additionally present summary statistics by social status. We find that particularly the burden of direct and indirect costs („Do you think your family can afford your university studies?" and "My parents think that I should work as soon as possible to support the family") differ between the students of lower and higher social background. Moreover, students of parents without any educational degree have a preference for high time discounting, while we do not find a significant difference between the mean for students from lower and from higher social class.
} 
tertiary education decreases significantly in the full model (Model B5, difference between logit ${ }^{28}$ coefficients calculated with the KHB method: $1.09 p=0.013$ ). A Blinder-Oaxaca decomposition further shows that the cost-benefit factors explain around 52 percent of the social background effect on students' study plans (see Table 2). This confirms that the cost-benefit variables account for an impressive part of the social background effect.

[Table 2 around here]

\footnotetext{
${ }^{28}$ It is not possible to calculate the test statistic for the difference between Average Marginal Effects from nested models with the KHB method. We therefore report the difference between logit coefficients even though we present Average Marginal Effects and Discrete Change Effects in Table 1.
} 
Table 2: Results from logistic regression models on students' study wishes and plans.

\begin{tabular}{|c|c|c|c|c|c|c|c|c|c|c|}
\hline & \multicolumn{5}{|c|}{ Students' study aspiration } & \multicolumn{5}{|c|}{ Students' study plan } \\
\hline & (A1) & $(\mathrm{A} 2)$ & (A3) & (A4) & (A5) & (B1) & (B2) & (B3) & (B4) & (B5) \\
\hline \multicolumn{11}{|l|}{$\begin{array}{l}\text { Parental Education } \\
\text { (Ref: No Degree): }\end{array}$} \\
\hline Primary school degree & $\begin{array}{l}0.087 \\
(0.053)\end{array}$ & $\begin{array}{c}0.089 \\
(0.052)\end{array}$ & $\begin{array}{l}0.100 \\
(0.054)\end{array}$ & & $\begin{array}{l}0.130^{*} \\
(0.052)\end{array}$ & $\begin{array}{l}0.206^{*} \\
(0.082)\end{array}$ & $\begin{array}{l}0.207^{*} \\
(0.081)\end{array}$ & $\begin{array}{l}0.145 \\
(0.088)\end{array}$ & & $\begin{array}{l}0.096 \\
(0.071)\end{array}$ \\
\hline Secondary school degree & $\begin{array}{l}0.043 \\
(0.050)\end{array}$ & $\begin{array}{l}0.046 \\
(0.047)\end{array}$ & $\begin{array}{l}0.053 \\
(0.047)\end{array}$ & & $\begin{array}{l}0.026 \\
(0.048)\end{array}$ & $\begin{array}{c}0.259 * * \\
(0.064)\end{array}$ & $\begin{array}{c}0.262^{* *} \\
(0.063)\end{array}$ & $\begin{array}{l}0.168^{*} \\
(0.064)\end{array}$ & & $\begin{array}{l}0.073 \\
(0.049)\end{array}$ \\
\hline Tertiary degree & $\begin{array}{l}0.074 \\
(0.095)\end{array}$ & $\begin{array}{l}0.068 \\
(0.092)\end{array}$ & $\begin{array}{l}0.086 \\
(0.076)\end{array}$ & & $\begin{array}{l}0.005 \\
(0.082)\end{array}$ & $\begin{array}{l}0.321^{* *} \\
(0.089)\end{array}$ & $\begin{array}{l}0.324^{* *} \\
(0.088)\end{array}$ & $\begin{array}{l}0.227^{*} \\
(0.091)\end{array}$ & & $\begin{array}{l}0.044 \\
(0.064)\end{array}$ \\
\hline $\begin{array}{l}\text { Parental Social Class } \\
\text { (Occupational prestige) }\end{array}$ & -0.028 & -0.040 & -0.049 & & -0.019 & $0.246 * *$ & $0.239 * *$ & $0.186^{* *}$ & & $0.089^{*}$ \\
\hline & $(0.086)$ & $(0.081)$ & $(0.069)$ & & $(0.061)$ & $(0.056)$ & $(0.054)$ & $(0.041)$ & & $(0.037)$ \\
\hline Grades & & $\begin{array}{c}0.063^{* *} \\
(0.018)\end{array}$ & $\begin{array}{l}0.061^{*} \\
(0.021)\end{array}$ & $\begin{array}{c}0.010 \\
(0.011)\end{array}$ & $\begin{array}{c}0.011 \\
(0.011)\end{array}$ & & $\begin{array}{l}0.059^{*} \\
(0.023)\end{array}$ & $\begin{array}{l}0.062^{*} \\
(0.024)\end{array}$ & $\begin{array}{l}0.024 \\
(0.024)\end{array}$ & $\begin{array}{c}0.022 \\
(0.023)\end{array}$ \\
\hline Age & & & $\begin{array}{c}-0.016+ \\
(0.008)\end{array}$ & $\begin{array}{c}-0.028^{* *} \\
(0.008)\end{array}$ & $\begin{array}{l}-0.027^{*} \\
(0.009)\end{array}$ & & & $\begin{array}{c}-0.039+ \\
(0.021)\end{array}$ & $\begin{array}{l}-0.045^{*} \\
(0.020)\end{array}$ & $\begin{array}{l}-0.034 \\
(0.020)\end{array}$ \\
\hline Female & & & $\begin{array}{l}0.067 \\
(0.040)\end{array}$ & $\begin{array}{c}0.040 \\
(0.046)\end{array}$ & $\begin{array}{l}0.047 \\
(0.045)\end{array}$ & & & $\begin{array}{l}0.007 \\
(0.040)\end{array}$ & $\begin{array}{c}0.019 \\
(0.042)\end{array}$ & $\begin{array}{c}0.033 \\
(0.041)\end{array}$ \\
\hline Has Children & & & $\begin{array}{l}-0.106 \\
(0.072)\end{array}$ & $\begin{array}{l}-0.079 \\
(0.070)\end{array}$ & $\begin{array}{l}-0.109 \\
(0.071)\end{array}$ & & & $\begin{array}{l}-0.120 \\
(0.085)\end{array}$ & $\begin{array}{l}-0.105 \\
(0.072)\end{array}$ & $\begin{array}{l}-0.112 \\
(0.068)\end{array}$ \\
\hline $\begin{array}{l}\text { Direct Costs } \\
\text { (Estimated Expenditures) }\end{array}$ & & & & $\begin{array}{l}-0.002 \\
(0.001)\end{array}$ & $\begin{array}{l}-0.002 \\
(0.001)\end{array}$ & & & & $\begin{array}{l}-0.001 \\
(0.002)\end{array}$ & $\begin{array}{l}-0.001 \\
(0.002)\end{array}$ \\
\hline $\begin{array}{l}\text { Indirect Costs } \\
\text { (Estimated Forgone Earnings) }\end{array}$ & & & & $\begin{array}{l}-0.003 \\
(0.002)\end{array}$ & $\begin{array}{l}-0.002 \\
(0.002)\end{array}$ & & & & $\begin{array}{l}-0.003 \\
(0.003)\end{array}$ & $\begin{array}{l}-0.003 \\
(0.003)\end{array}$ \\
\hline Burden of Direct Costs I & & & & 0.006 & 0.004 & & & & $0.351 * * *$ & $0.325^{* * *}$ \\
\hline (Affordability University) & & & & $(0.058)$ & $(0.056)$ & & & & $(0.037)$ & $(0.040)$ \\
\hline Burden of Direct Costs II & & & & $0.054 * *$ & $0.057^{* *}$ & & & & 0.008 & 0.014 \\
\hline (Economic challenge) & & & & $(0.013)$ & $(0.013)$ & & & & $(0.019)$ & $(0.021)$ \\
\hline Burden of Indirect Costs & & & & -0.025 & -0.030 & & & & -0.017 & -0.017 \\
\hline (Need to Support Family) & & & & $(0.017)$ & $(0.017)$ & & & & $(0.012)$ & $(0.011)$ \\
\hline Subjective Success Prob. & & & & $0.128^{* * *}$ & $0.132 * * *$ & & & & $0.082^{*}$ & $0.079^{*}$ \\
\hline (Academic Confidence) & & & & $(0.016)$ & $(0.018)$ & & & & $(0.028)$ & $(0.025)$ \\
\hline Economic Benefits & & & & 0.002 & 0.002 & & & & $0.003^{*}$ & $0.003^{*}$ \\
\hline (Estimated Returns of Tertiary E.) & & & & $(0.001)$ & $(0.001)$ & & & & $(0.001)$ & $(0.001)$ \\
\hline Social Benefits & & & & 0.038 & 0.042 & & & & -0.007 & -0.001 \\
\hline
\end{tabular}




\begin{tabular}{|c|c|c|c|c|c|c|c|c|c|c|}
\hline (Estimated Returns Status) & & & & $(0.027)$ & $(0.027)$ & & & & (0.029) & $(0.032)$ \\
\hline \multirow[t]{2}{*}{ Status Maintenance Parents } & & & & 0.003 & 0.005 & & & & $0.039 *$ & $0.038^{*}$ \\
\hline & & & & $(0.011)$ & $(0.011)$ & & & & $(0.012)$ & $(0.012)$ \\
\hline \multirow[t]{2}{*}{ Risk Averse Individual } & & & & 0.031 & 0.031 & & & & -0.008 & -0.010 \\
\hline & & & & $(0.024)$ & $(0.024)$ & & & & (0.039) & (0.039) \\
\hline \multirow[t]{2}{*}{ High Time Discounting } & & & & -0.013 & -0.005 & & & & $-0.119^{*}$ & $-0.101^{*}$ \\
\hline & & & & $(0.033)$ & $(0.037)$ & & & & $(0.040)$ & $(0.040)$ \\
\hline $\mathbf{N}$ & 445 & 445 & 445 & 445 & 445 & 448 & 448 & 448 & 448 & 448 \\
\hline
\end{tabular}

Standard error in parentheses, ${ }^{+} p<0.1,{ }^{*} p<0.05,{ }^{* *} p<0.01,{ }^{* * *} p<0.001$

AME and DCE's reported, controlled for type of high school, municipalities with entry examinations, regions, and zones. 
To better understand the exact mechanisms behind this reduction, the role of each of the costbenefit factors was analysed in detail focussing on (1) direct effects, (2) mediation effects, and, if justified by theoretical reasoning, (3) heterogeneous effects.

As we argued in the theoretical section, cost considerations might play a crucial role in determining whether students plan to continue with tertiary education. Our findings in Table 2 and Models B4 and B5 support this assumption. Particularly the burden of direct costs is a strong predictor of individual educational perspectives. Students' perception on whether studying would be challenging for their family's economic resources significantly decreases the probability of having study wishes (Model A5), while their perception on whether their family can afford their tertiary education significantly increases the probability of having study plans (Model B5). However, we find neither wishes nor plans to be influenced by students' evaluation on the necessity to support the family (burden of indirect costs). But do these cost considerations mediate the social background effect? Already the bivariate analyses (see Table A2 in Appendix) indicate that this might be the case as low background students report a significantly higher burden of direct and indirect costs. The detailed decomposition in Table 3 finally confirms this assumption: Depending on the model specification, the cost factors explain between 40 and 50 percent of the social background effect regarding study plans. A closer look at each of the cost variables further reveals that this impressive mediation effect is almost entirely driven by the perceived affordability of university studies (see Table A3), while there is no evidence that the absolute burden of (in)direct costs or cost-related information biases (see Table A2) contribute to the observed educational differentials.

[Table 3 around here] 
Table 3: Blinder-Oaxaca decomposition

\begin{tabular}{|c|c|c|c|c|}
\hline \multirow[b]{2}{*}{ Soc. Background: } & \multicolumn{2}{|c|}{$\begin{array}{l}\text { Students' study } \\
\text { aspiration }\end{array}$} & \multicolumn{2}{|c|}{$\begin{array}{l}\text { Students' study } \\
\text { plans }\end{array}$} \\
\hline & Education & Social Class & Education & Social Class \\
\hline \multicolumn{5}{|l|}{ Overall } \\
\hline Higher soc. back. & $\begin{array}{c}0.784 * * * \\
(0.029)\end{array}$ & $\begin{array}{c}0.752 * * * \\
(0.026)\end{array}$ & $\begin{array}{c}0.677^{* * *} \\
(0.046)\end{array}$ & $\begin{array}{c}0.590 * * * \\
(0.044)\end{array}$ \\
\hline Lower soc. back. & $\begin{array}{c}0.737 * * * \\
(0.030)\end{array}$ & $\begin{array}{c}0.760 * * * \\
(0.034)\end{array}$ & $\begin{array}{c}0.300 * * * \\
(0.026)\end{array}$ & $\begin{array}{c}0.317^{* * *} \\
(0.030)\end{array}$ \\
\hline Difference & $\begin{array}{l}0.047 \\
(0.034)\end{array}$ & $\begin{array}{l}-0.008 \\
(0.044)\end{array}$ & $\begin{array}{c}0.377^{* * *} \\
(0.052)\end{array}$ & $\begin{array}{c}0.273 * * * \\
(0.048)\end{array}$ \\
\hline Explained & $\begin{array}{l}-0.022 \\
(0.033)\end{array}$ & $\begin{array}{c}0.026 \\
(0.020)\end{array}$ & $\begin{array}{c}0.261^{* * *} \\
(0.054)\end{array}$ & $\begin{array}{c}0.267^{* * *} \\
(0.045)\end{array}$ \\
\hline Unexplained & $\begin{array}{c}0.069 \\
(0.039)\end{array}$ & $\begin{array}{l}-0.034 \\
(0.042)\end{array}$ & $\begin{array}{l}0.116^{*} \\
(0.051)\end{array}$ & $\begin{array}{c}0.005 \\
(0.032)\end{array}$ \\
\hline \multicolumn{5}{|l|}{ Explained } \\
\hline Grades & $\begin{array}{c}0.001 \\
(0.001)\end{array}$ & $\begin{array}{c}0.001 \\
(0.002)\end{array}$ & $\begin{array}{c}0.001 \\
(0.002)\end{array}$ & $\begin{array}{c}0.002 \\
(0.004)\end{array}$ \\
\hline Costs & $\begin{array}{l}-0.028 \\
(0.033)\end{array}$ & $\begin{array}{l}-0.027 \\
(0.026)\end{array}$ & $\begin{array}{c}0.148^{* * *} \\
(0.026)\end{array}$ & $\begin{array}{c}0.139 * * * \\
(0.029)\end{array}$ \\
\hline Success & $\begin{array}{c}0.014 \\
(0.018)\end{array}$ & $\begin{array}{c}0.018 \\
(0.012)\end{array}$ & $\begin{array}{c}0.010 \\
(0.009)\end{array}$ & $\begin{array}{c}0.012 \\
(0.008)\end{array}$ \\
\hline Utility & $\begin{array}{l}-0.003 \\
(0.008)\end{array}$ & $\begin{array}{l}-0.007 \\
(0.006)\end{array}$ & $\begin{array}{c}0.013 \\
(0.015)\end{array}$ & $\begin{array}{c}0.001 \\
(0.011)\end{array}$ \\
\hline Psycholog. factors & $\begin{array}{l}0.000 \\
(0.004)\end{array}$ & $\begin{array}{l}-0.000 \\
(0.002)\end{array}$ & $\begin{array}{l}0.013+ \\
(0.007)\end{array}$ & $\begin{array}{c}0.003 \\
(0.006)\end{array}$ \\
\hline Controls & $\begin{array}{l}0.010 \\
(0.025)\end{array}$ & $\begin{array}{c}0.010 \\
(0.021)\end{array}$ & $\begin{array}{c}0.073 \\
(0.045)\end{array}$ & $\begin{array}{c}0.062 \\
(0.035)\end{array}$ \\
\hline $\begin{array}{l}\text { Other social } \\
\text { background var. }\end{array}$ & $\begin{array}{l}-0.015 \\
(0.024)\end{array}$ & $\begin{array}{c}0.030 \\
(0.017)\end{array}$ & $\begin{array}{c}0.003 \\
(0.017)\end{array}$ & $\begin{array}{l}0.048+ \\
(0.023)\end{array}$ \\
\hline
\end{tabular}

Two-fold decomposition using pooled model

Standard error in parentheses, ${ }^{+} p<0.1,{ }^{*} p<0.05,{ }^{* *} p<0.01,{ }^{* * *} p<0.001$

Logit coefficients reported

Education: Low social background = parents do not have an educational degree. High social background = parents have at least an elementary degree

Social Class: Low social background $=$ Below and at median. High social background $=$ Above median

Always additionally controlled for the other social background variable

Previous research in high-income countries has shown that the primary effect of social origin and students' self-assessed success probability are an important factor in the decision-making process. In our models in Table 2, the actual ability of the students (measured with grades) explains part of students' wishes and study plans (Model A2 and B2) but loses its predictive value as soon as we include students' self-assessed success probability (Model A4 and B4). Academic confidence has a positive effect in all models and is actually the single most important variable explaining students' study aspirations (Model A5). However, students' self-assessed ability only plays a subordinate role in 
determining whether they actually realise these aspirations (Model B5). We further do not find that these variables contribute to the mediation of the social background effects, as their explanatory value in the detailed decomposition in Table 3 is negligible. We also tested whether the assessment of the success probability is biased by social background, which does not seem to be the case (see Table A2 in the Appendix). In our theoretical section we further argued that we might find a heterogeneous effect based on social background: A positive assessment of ability is probably more important for students with less financial means because they cannot afford to prolong their university careers or because they have to attend the more demanding but less expensive public universities. The respective results in Figure 4 are inconclusive though. While we do find grades to affect aspirations of students with less educated parents more strongly (bootstrapped difference between estimates $=-0.099, p=$ $0.020)$, the corresponding estimates for academic confidence do not differ significantly. Moreover, study plans do not seem to be affected differently by grades or academic confidence depending on students' social background.

[Figure 4 around here]

The effects of the variables related to utility considerations are mixed, as can be seen in Table 2. In correspondence with our theoretical reasoning, we find that individuals expecting higher economic returns to tertiary education have a higher probability to plan to pursue it (Model B4 and B5). However, social benefit considerations do not seem to play a role in the decision-making process. Finally, students who believe that their parents value status maintenance have also a higher likelihood to plan to continue with tertiary education (Model B5). However, all these variables only play a minor role in explaining social-class based differences in educational decision-making, as can be seen in the Blinder-Oaxaca decomposition in Table 3, most likely because respondents from different social backgrounds assess these benefits similarly. Thus, in contrast to Barone et al. (2018), we do not find that lower social background students are biased in their assessment of expected economic benefits (see Table A2). ${ }^{29}$ Following our theoretical reasoning, we also checked whether we find heterogeneous effect for status maintenance (since lower social background students already surpassed their parents' educational degree by far, their choices should be driven by fear of status loss). However, Figure 4 does not point towards heterogeneous effects.

\footnotetext{
${ }^{29}$ On average, our respondents expect a tertiary wage premium of 245 percent, which is very similar to the 230 percent estimated by Bashir and Luque (2012).
} 
Figure 4: Interaction effects presented as AMEs and DCEs for subgroups

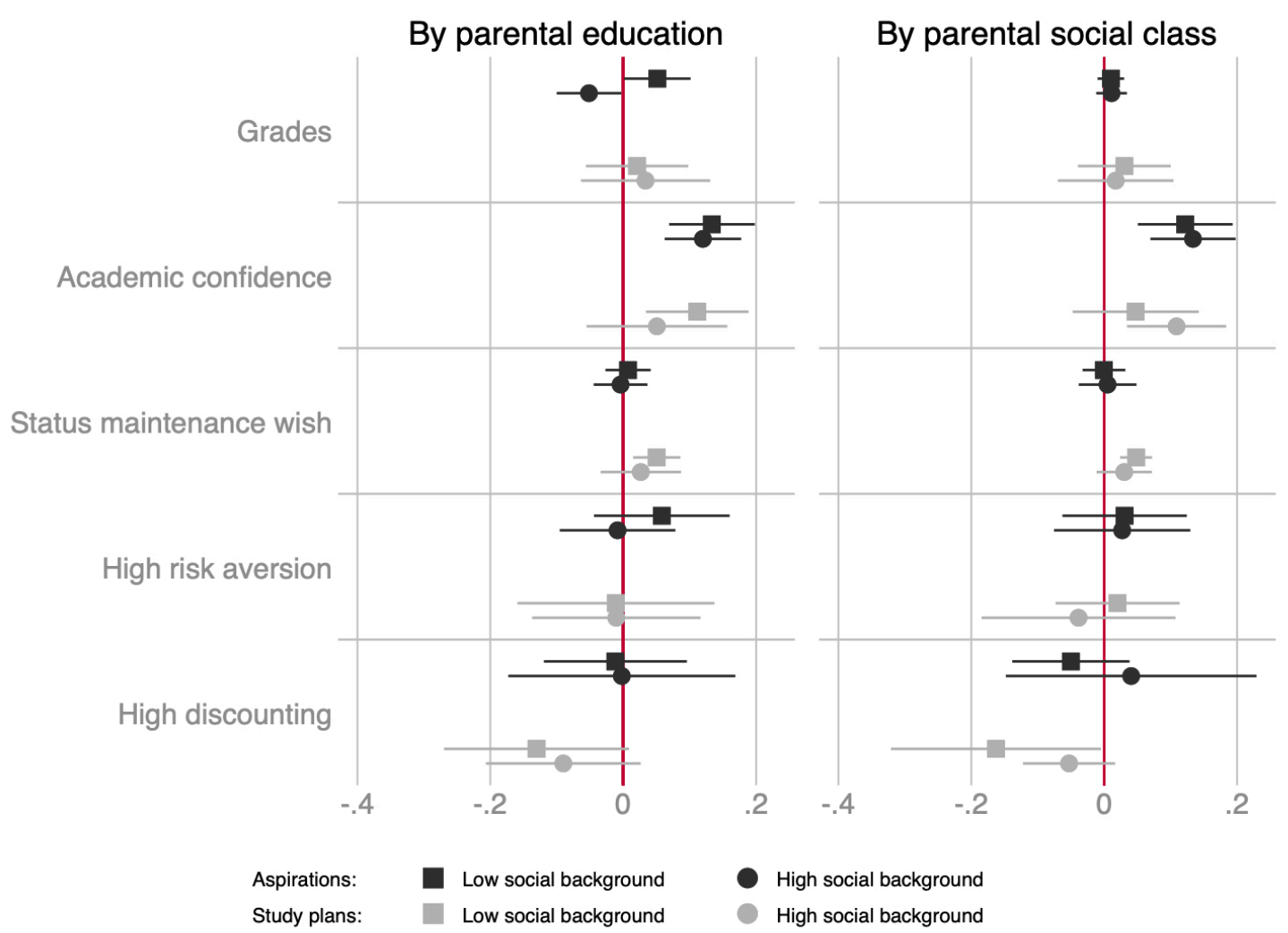

Notes: Coefficients are AMEs and DCEs, calculated separately for low and high social background students. Estimates are based on Models 3 in Table 1 with binarized social background variables (same operationalization as for the Blinder-Oaxaca decomposition). Some of the differences between the coefficients have been bootstrapped (250 replications).

Lastly, we assess the importance of the psychological variables related to the perceived utility of education. Contrary to our expectations as well as results from Breen et al. (2014), we do not find that individual risk aversion affects students' decision-making, as can be seen in Table 2. However, our findings regarding time discounting preferences are consistent with Breen et al. (2014). Students with a high time discount rate are less likely to plan to continue tertiary education (Model B4 and B5). As to status differentials, the bivariate results in Table A2 in the Appendix show that, while students with lower educated parents do not differ substantially from higher-status students regarding risk aversion, they indeed exhibit a higher time discount rate. Nevertheless, the psychological factors contribute little to explaining the class-dependent decision-making (see Blinder-Oaxaca decomposition in Table 3). Finally, following Breen et al. 2014, we also tested whether lower social background students react more strongly to higher risk aversion and higher time discounting preferences. However, the results in Figure 4 are inconclusive. In contrast to Breen et al. (2014), we do not observe a heterogeneous effect 
for risk preferences. Also in contrast to our own theoretical reasoning, we do not find that higher time discounting preferences affect lower social background students more strongly as the difference between the estimates of the two status groups fails to reach conventional levels of statistical significance. ${ }^{30}$

\section{Conclusion}

This paper provided an examination of educational decision-making in a context of widespread poverty, a non-functioning welfare state and a lack of affordable loans - characteristics shared by most low- and middle-income countries. Analyses based on high-income countries showed that success probability and costs (especially on tertiary level) are important drivers of educational choices, but that these factors not always mediate the social background effect (e.g. Stocké 2007, Barone et. al. 2018). However, it remains unclear whether these results are also applicable in a different socio-economic context. For this reason, this study analysed the mechanisms of educational decision-making through a survey with a random sample of 450 high school students in the department of Morazán in EI Salvador.

The story behind class-based educational decision-making in Morazán turned out to be fairly simple. Regardless of social background, almost all students wish to pursue tertiary education, particularly if they believe that their success probability is high. This result diverges from previous findings from high-income countries, where aspirations tend to differ by social background. The high educational aspirations across social classes may be driven by the huge premium in annual earnings for a tertiary degree in El Salvador and are consistent with students' high occupational aspirations across all status groups. However, our analyses also show that most lower social background students cannot realise their study aspirations. We find that the perceived burden of the direct costs is the main driver behind this gap between aspiration and plans for disadvantaged students as it explains between 40 and 50 percent of the social background effect. This finding differs substantially from previous research conducted in high-income countries, where cost factors do not play a role at all in early transitions and a negligible one in accounting for status differentials in educational outcomes. The great importance of the cost burden is consistent with our theoretical expectations. Low social

\footnotetext{
${ }^{30}$ We also calculated multinomial logit models to assess whether different factors are important for students who want to pursue tertiary education at a public versus a private university. Results are in line with our theoretical arguments. We find that students who want to pursue tertiary education at a public university are more sensitive to costs, academic confidence, and their individual risk aversion because public university is less expensive and academically more demanding (results are available at the GESIS repository).
} 
background students in Morazán often live in absolute poverty, i.e. in households that are struggling for economic survival and thus often simply unable to finance education careers or in desperate need for an additional income source. In the absence of affordable loans or redistributive policies, regardless of their talent or motivation, lower background students may thus fail to make profitable investments in education due to credit constraints. Besides the pivotal importance of cost-related factors in the process of educational decision-making, we find other cost-benefit variables to play a role too. The perceived success probability is the most important predictor for students' study aspirations. Furthermore, expected economic benefits, parental status maintenance wish and low time discounting preferences slightly increase the probability that an individual plans to continue with tertiary education. However, these factors do not substantially contribute to status differentials in educational outcomes. Neither do we observe primary effects of social origin measured with students' grades. Lower social background students do not have worse grades and, consequently, grades do not account for social background effects in educational choices. This stands in contrast to vast evidence documenting for many high-income countries that the primary effect of social origin still has a nonnegligible effect at the transition to tertiary education (e.g. Jackson 2013). Overall, our findings suggest that rational choice models are well suited for explaining class-based educational differential in setting of economic deprivation. Since study aspirations are found to be largely unrelated to social background, we have no reason to conclude that students from lower backgrounds do not value further education or that they do not perceive it as an option they are expected to consider. Quite on the contrary, they seem to be well aware of the benefits, costs and risks associated with tertiary education and have come to the conclusion that this path is financially unavailable to them.

This study has made two important contributions: First, it has helped to better understand the process of (class-based) educational decision-making in a context of widespread poverty. A deeper understanding of the mechanisms behind individual and class-based choices regarding schooling is indispensable, if educational inequalities and inefficiencies are to be addressed. Second, our study also contributed to the theoretical research on educational decision-making by providing a test of the accuracy of the rational choice models in an empirical setting completely different from that of previous validations. While the model proved to have an impressive explanatory power, findings regarding the importance of the different factors differ from previous results for high-income countries.

Some shortcomings of this study should not go unmentioned. First only educational plans, but no actual educational outcomes could be studied. Second, our data relies on self-reports, which may not always be accurate due to social desirability biases or rationalization processes. It might thus be informative to collect further information on actual transitions in future surveys and validate student's 
self-reports with data obtained through parents or teachers. Third, it must be noted that we could only study transitions to tertiary education for the selective subsample of youth who are still in the educational system at this point. While this enabled us to better understand the mechanisms behind the educational decisions of those who get to make them, we have to bear in mind that these youth are not likely to be representative for their cohort. In particular, they can be expected to be more motivated and affluent than their peers who have dropped out at an earlier stage of their educational careers. Finally, our analyses could suffer from the endogeneity problems inherent to all investigations based on non-experimental data. This means that the observed relationships may not necessarily result from the causal channels proposed by our theoretical reasoning, but could also be produced by confounding variables or reversed causality. In an ideal setting, one would experimentally manipulate each factor in the model for students from different social backgrounds and observe the effects on educational transitions. Since such an approach is not feasible in practice, there is still much we can learn from the careful analysis of observational data.

These shortcomings notwithstanding, our results have important consequences for local policy making. Our analyses showed that almost all students (and their families) perceive returns to higher education and their success probability to be high enough to consider the investment in tertiary education to be profitable - regardless of their social background. Whether they will finally pursue tertiary education depends primarily on their access to financing. Hence, if equal chances or meritocracy are to be promoted, tertiary education has to be made affordable for the poor. For example, conditional cash transfer programs or study loans could provide financial aid to talented students from disadvantaged backgrounds. ${ }^{31}$ Furthermore, alternatives to academic (or semiacademic) education such as vocational education training might be introduced. These could not only serve to provide professional qualifications to all those who cannot go to university, but also create a higher diversity in skills and knowledge. Taken together, such measures might help to prevent a highly inefficient and unjust allocation, where the rich rather than the talented and motivated acquire further education, thereby contributing to an inclusive and sustainable development process.

\footnotetext{
${ }^{31}$ Note that as vocational education training tends to be shorter and usually and involves a small salary, it would be an attractive option for low-income students facing financial constraints. While this would clearly not eliminate inequalities in access to academic careers, it could help prevent low status students from discontinuing their educational careers altogether.
} 


\section{Literature}

Andrew, M. \& Hauser, R. M. (2010). Adoption? Adaptation? Evaluation the Formation of Educational Expectations. Social Forces, 90, 497-520.

Baez, J.E. \& Camacho, A. (2011). Assessing the long-term effects of conditional cash transfers on human capital. Evidence from Colombia. The World Bank.

Banerjee, Abhijit V. (2003). Contracting Constraints, Credit Markets, and Economic Development. Advances in Economics and Econometrics: Theory and Applications, Eighth World Congress, Vol. 3. Cambridge University Press.

Barone, C., Triventi, M. \& Assirelli, G. (2018). Explaining Social Inequalities in Access to University. A Text of Rational Choice Mechanisms in Italy. European Sociological Review, 34, 554-569.

Bashir, S. \& Luque, J. A. (2012). Equity in Tertiary Education in Central America: An Overview. Rochester, NY: Social Science Research Network.

Becker, G. S. (1962). Investment in human capital. A theoretical analysis. Journal of Political Economy, 70, 9-49.

Becker, R. (2003). Educational expansion and persistent inequalities of education - Utilizing subjective expected utility theory to explain increasing participation rates in upper secondary school in the Federal Republic of Germany. European Sociological Review, 19, 1-24.

Berger, J. \& Combet, B. (2017). Late School Tracking, Less Class Bias in Educational Decision-Making? The Uncertainty Reduction Mechanism and Its Experimental Testing. European Sociological Review, 33, 124-136.

Boudon, R. (1974). Education, Opportunity, and Social Inequality. Changing Prospects in Western Societies. New York, etc.: John Wiley \& Sons.

Bourdieu, P. (1979). Distinction. A Social Critique of the Judgement of Taste. Cambridge, MA: Harvard University Press.

Bozick, R., Alexander, K., Entwisle, D., Dauber, S. \& Kerr, K. (2010). Framing the Future. Revisiting the Place of Educational Expectations in Status Attainment. Social Forces, 88, 2027-2052.

Breen, R. \& Goldthorpe, J. H. (1997). Explaining educational differentials - Towards a formal rational action theory. Rationality and Society, 9, 275-305.

Breen, R., Van De Werfhorst, H. G. \& Jaeger, M. M. (2014). Deciding under Doubt: A Theory of Risk Aversion, Time Discounting Preferences, and Educational Decision-making. European Sociological Review, 30, 258-270.

Buchmann, C. \& Dalton, B. (2002). Interpersonal Influences and Educational Aspirations in 12 Countries. The Importance of Institutional Context. Sociology of Education, 75, 99-122.

Daude, C. \& Robano, V. (2015). On intergenerational (im)mobility in Latin America. Latin American Economic Review, 24, 1-29. 
Davies, R., Heinesen, E. \& Holm, A. (2002). The relative risk aversion hypothesis of educational choice. Journal of Population Economics, 15, 683-713.

Erikson, R. \& Jonsson, J. O. (1996). Can education be equalized?: The Swedish case in comparative perspective. Westview Press.

Filmer, D. \& Pritchett, L. (1999). The effect of household wealth on educational attainment. Evidence from 35 countries. Population and Development Review, 25, 85-120.

Gabay-Egozi, L., Shavit, Y. \& Yaish, M. (2010). Curricular Choice: A Test of a Rational Choice Model of Education. European Sociological Review, 26, 447-463.

Haller, A. O. (1968). On the concept of aspiration. Rural Sociology, 33, 484-487.

Jackson, M. (2013). Determined to Succeed. Performance versus Choice in Educational Attainment. Stanford: Stanford University Press.

Jann, B. (2007a). Making Regression Tables Simplified. The Stata Journal, 7, 227-244.

Jann, B. (2007b). FRE: Stata Module to Display One-Way Frequency Table. Statistical Software Components S456835. Boston College Department of Economics, revised June 3, 2015.

Jann, B. (2008). The Blinder-Oaxaca decomposition for linear regression models. The Stata Journal, 8, 453-479.

Jann, B. (2014). Plotting Regression Coefficients and Other Estimates. The Stata Journal, 14, 708-737.

Jann, B. (2018a). Customizing Stata Graphs Made Easy (part 1). The Stata Journal, 18, 491-502.

Jann, B. (2018b). Customizing Stata Graphs Made Easy (part 2). The Stata Journal, 18, 786-802.

Kahneman, D. \& Tversky, A. (1979). Prospect Theory: An Analysis of Decision under Risk. Econometrica, 47, 263-291.

Karlson, K., Holm, A. \& Breen, R. (2011). Comparing Regression Coefficients Between Same-sample Nested Models using Logit and Probit. A New Method. Sociological Methodology, 42, 286-313.

Kilburn, K., Handa, S., Angeles, G., Mvula, P., \& Tsoka, M. (2017). Short-term impacts of an unconditional cash transfer program on child schooling: Experimental evidence from Malawi. Economics of education review, 59, 63-80.

Klein, Daniel (2014). MIMRGNS: Stata moduel to run margins after mi estimate. Statistical Software Components S457795. Boston College Department of Economics, revised 22 Sep 2019.

Klein, Daniel (2018). Implementing a general framework for assessing interrater agreement in Stata. The Stata Journal, 18, 872-901.

Kohler, U.; Karlson, K.B.; Holm, A (2011). Comparing coefficients of nested nonlinear probability models. The Stata Journal, 11, 420-438.

Lanjouw, P. (2001). Nonfarm Employment and Poverty in Rural El Salvador. World Developent, 29: 529547. 
Loyalka, P., Liu, C., Song, Y., Yi, H., Huang, X., Wei, J., Zhang, L., Shi, Y., Chu, J., \& Rozelle, S. (2013). Can information and counseling help students from poor rural areas go to high school? Evidence from China. Journal of Comparative Economics, 41, 1012-1025.

Mo, D., Zhang, L., Yi, H., Luo, R., Rozelle, S., \& Brinton, C. (2013). School dropouts and conditional cash transfers: Evidence from a randomised controlled trial in rural China's junior high schools. The Journal of Development Studies, 49, 190-207.

Morgan, S. L. (2005): On the Edge of Commitment. Educational Attainment and Race in the United States. Stanford University Press.

Murakami, Y. \& Blom, A. (2008). Accessibility and affordability of tertiary education in Brazil, Colombia, Mexico and Peru within a global context. Rochester, NY: Social Science Research Network.

Nguyen, Trang. (2008). Information, role models and perceived returns to education: Experimental evidence from Madagascar. Unpublished manuscript.

Oaxaca, R. L. \& Ransom, M. R. (1994). On discrimination and the decomposition of wage differentials. Journal of econometrics, 61, 5-21.

Rosenblum, D. (2009). Measuring Inequality of Opportunities in Latin America and the Caribbean. Journal of Economic Literature, 47, 1152-1154.

Schindler, S. \& Reimer, D. (2011). Differentiation and social selectivity in German higher education. Higher Education, 61, 261-275.

Schultz, T. P. (2004). School subsidies for the poor: evaluating the Mexican Progresa poverty program. Journal of Development Economics, 74, 199-250.

Shah, A. K.; Mullainathan, S. \& Shafir, E. (2012). Some Consequences of Having Too Little. Science, 388, 682-685.

Stocké, V. (2007). Explaining educational decision and effects of families' social class position: An empirical test of the Breen-Goldthorpe model of educational attainment. European Sociological Review, 23, 505-519.

Tolsma, J.; Need, A. \& de Jong, U. (2010). Explaining Participation Differentials in Dutch Higher Education. The Impact of Subjective Success Probabilities on Level Choice and Field Choice. European Sociological Review, 26, 235-252.

Torche, F. \& Spilerman, S. (2008). Household Wealth in Latin America. In Davies, James (ed.): Personal Wealth from a Global Perspective. Oxford: University Press.

Traynor, A. \& Raykov, T. (2013). Household Possessions Indices as Wealth Measures: A Validity Evaluation. Comparative Education Review, 57, 662-688.

Unesco, U. N. E., Scientific and Cultural Organization (2012). El Salvador. World Data on Education. Online Document: http://www.ibe.unesco.org/en/document/world-data-education-seventhedition-2010-11 (accessed: 3. January 2020).

Vaisey, Stephen (2010). What People Want. Rethinking Poverty, Culture, and Educational Attainment. The Annals of the American Academy of Political and Socical Science, 629 , 75-101. 
World Bank Group (2018). Learning to realize education's promise. World Bank Group Flagship Report.

Van De Werfhorst, H. G. V. \& Hofstede, S. (2007). Cultural capital or relative risk aversion? Two mechanisms for educational inequality compared. British Journal of Sociology, 58, 391-415.

Yun, M.-S. (2004). Decomposing differences in the first moment. Economics letters, 82, 275-280. 


\section{Appendix}

Table A1: Operationalisation and descriptive statistics (weighted, and based on imputed dataset)

\begin{tabular}{|c|c|c|c|}
\hline & $\begin{array}{l}\text { Wording (translated from } \\
\text { Spanish and summarized) }\end{array}$ & Coding/Measure & $\begin{array}{l}\text { Descriptive } \\
\text { statistics }\end{array}$ \\
\hline \multicolumn{4}{|l|}{ Dependent variables: } \\
\hline Study aspiration & $\begin{array}{l}\text { If anything was possible: } \\
\text { What would you like to do } \\
\text { after graduating from high } \\
\text { school? }\end{array}$ & $\begin{array}{l}\text { Academic studies }=1 \\
\text { Technical studies }=1 \\
\text { Work }=0 \\
\text { Housework }=0 \\
\text { Migration }=0\end{array}$ & $\begin{array}{l}0=23.70 \% \\
1=76.30 \%\end{array}$ \\
\hline Study plan & $\begin{array}{l}\text { What do you plan to do } \\
\text { after graduating from high } \\
\text { school? }\end{array}$ & $\begin{array}{l}\text { Academic studies }=1 \\
\text { Technical studies }=1 \\
\text { Work }=0 \\
\text { Housework }=0 \\
\text { Migration }=0\end{array}$ & $\begin{array}{l}0=55.98 \% \\
1=44.02 \%\end{array}$ \\
\hline \multicolumn{4}{|c|}{ Social background variables: } \\
\hline Parental education & $\begin{array}{l}\text { What is your mother's / } \\
\text { father's highest } \\
\text { educational degree? }\end{array}$ & $\begin{array}{l}\text { Highest status of both } \\
\text { parents: } \\
\text { no educational degree }=0 \\
\text { primary degree }=1 \\
\text { secondary degree }=2 \\
\text { tertiary degree (university or } \\
\text { technical) }=3\end{array}$ & $\begin{array}{l}0=61.22 \% \\
1=11.63 \% \\
2=15.97 \% \\
3=11.08 \%\end{array}$ \\
\hline $\begin{array}{l}\text { Parental social class } \\
\text { (occupational } \\
\text { prestige) }\end{array}$ & $\begin{array}{l}\text { What is your } \\
\text { father's/mother's } \\
\text { occupation? What does } \\
\text { your father/mother do } \\
\text { during his/her work? }\end{array}$ & $\begin{array}{l}\text { Average of the rating of } 8 \mathrm{El} \\
\text { Salvadorian coders of parents' } \\
\text { occupations based on two } \\
\text { questions (rating from on } 1 \\
\text { (low prestige) to } 3 \text { (high } \\
\text { prestige)). }\end{array}$ & $\begin{array}{l}\text { Mean }=1.355 \\
\text { Std. Dev. =0.019 } \\
\text { Median }=1.25 \\
\text { Min. }=1 \\
\text { Max. = 2.75 }\end{array}$ \\
\hline \multicolumn{4}{|l|}{ Cost-related variables: } \\
\hline Direct costs (absolute) & $\begin{array}{l}\text { Imagine you continue your } \\
\text { studies after high school: } \\
\text { How much do you think } \\
\text { you would spend for your } \\
\text { studies (for books, } \\
\text { transportation, food, } \\
\text { tuition fees, etc.)? }\end{array}$ & $\begin{array}{l}\text { Monthly expenses / } 10 \\
\text { (individuals with implausible } \\
\text { values above } 1000 \text { USD were } \\
\text { excluded from the analyses } \\
(\mathrm{N}=8) \text { ) }\end{array}$ & $\begin{array}{l}\text { Mean }=22.698 \\
\text { Std. Dev. }=0.738 \\
\text { Median }=20 \\
\text { Min. }=0.1 \\
\text { Max. }=100\end{array}$ \\
\hline $\begin{array}{l}\text { Indirect costs } \\
\text { (absolute) }\end{array}$ & $\begin{array}{l}\text { Imagine you want to work } \\
\text { after high school. Do you } \\
\text { think that you would find a } \\
\text { job? } \\
\text { Imagine you start to work } \\
\text { after high school: How } \\
\text { much do you think you } \\
\text { would earn? }\end{array}$ & $\begin{array}{l}\text { Product of estimated } \\
\text { probability of finding a job } \\
\text { and expected earnings in USD } \\
\text { / } 10\end{array}$ & $\begin{array}{l}\text { Mean }=8.204 \\
\text { Std. Dev. }=0.384 \\
\text { Median }=6 \\
\text { Min }=0 \\
\text { Max }=60\end{array}$ \\
\hline $\begin{array}{l}\text { Burden of direct costs } \\
\text { I (relative) }\end{array}$ & $\begin{array}{l}\text { Do you think your family } \\
\text { can afford your university } \\
\text { studies? }\end{array}$ & $\begin{array}{l}\text { No }=0 \\
\text { Yes }=1\end{array}$ & $\begin{array}{l}0=53.50 \% \\
1=46.50 \%\end{array}$ \\
\hline $\begin{array}{l}\text { Burden of direct costs } \\
\text { II (relative) }\end{array}$ & $\begin{array}{l}\text { How difficult would it be } \\
\text { for your family to pay for } \\
\text { your university studies? }\end{array}$ & $\begin{array}{l}\text { very easy }=1 \\
{[\ldots]} \\
\text { very difficult }=6\end{array}$ & $\begin{array}{l}1=2.26 \% \\
2=2.71 \% \\
3=10.61 \% \\
4=35.89 \%\end{array}$ \\
\hline
\end{tabular}




\begin{tabular}{|c|c|c|c|}
\hline & & & $\begin{array}{l}5=23.02 \% \\
6=25.51 \%\end{array}$ \\
\hline $\begin{array}{l}\text { Burden of indirect } \\
\text { costs (relative) }\end{array}$ & $\begin{array}{l}\text { My parents think that I } \\
\text { should work as soon as } \\
\text { possible to support the } \\
\text { family }\end{array}$ & $\begin{array}{l}\text { Not at all true }=1 \\
{[\ldots]} \\
\text { Completely true }=6\end{array}$ & $\begin{array}{l}1=6.40 \% \\
2=6.63 \% \\
3=15.24 \% \\
4=16.58 \% \\
5=28.71 \% \\
6=26.44 \%\end{array}$ \\
\hline \multicolumn{4}{|c|}{ Success Probability Variables } \\
\hline $\begin{array}{l}\text { Objective success } \\
\text { probability }\end{array}$ & $\begin{array}{l}\text { What was your average } \\
\text { school grade in this } \\
\text { trimester? }\end{array}$ & $\begin{array}{l}\text { Average degree, standardized } \\
\text { by school class }\end{array}$ & $\begin{array}{l}\text { Mean }=0.000 \\
\text { Std. Dev. }=0.046 \\
\text { Median }=-0.025 \\
\text { Min. }=-2.91 \\
\text { Max. }=2.72\end{array}$ \\
\hline $\begin{array}{l}\text { Subjective success } \\
\text { probability }\end{array}$ & $\begin{array}{l}\text { I have the abilities for a } \\
\text { university career }\end{array}$ & $\begin{array}{l}\text { not at all true }=1 \\
{[\ldots]} \\
\text { completely true }=6\end{array}$ & $\begin{array}{l}1=0.23 \% \\
2=0.23 \% \\
3=3.41 \% \\
4=11.61 \% \\
5=35.15 \% \\
6=49.38 \%\end{array}$ \\
\hline \multicolumn{4}{|c|}{ Benefit-related variables } \\
\hline Economic benefits & $\begin{array}{l}\text { Imagine you want to work } \\
\text { after high school: Do you } \\
\text { think that you would find a } \\
\text { job? How much do you } \\
\text { think you would earn in } \\
\text { that case per month? } \\
\text { Imagine you graduated } \\
\text { from university and wanted } \\
\text { to work: Do you think that } \\
\text { you would find a job? How } \\
\text { much do you think you } \\
\text { would earn in that case per } \\
\text { month? }\end{array}$ & $\begin{array}{l}\text { Absolute increase in expected } \\
\text { earnings: difference between } \\
\text { the products of the } \\
\text { probability of labour market } \\
\text { participation and the salary } \\
\text { for university graduates and } \\
\text { high school graduates } \\
\text { respectively / } 10\end{array}$ & $\begin{array}{l}\text { Mean }=18.117 \\
\text { Std. Dev. }=0.892 \\
\text { Median }=13.60 \\
\text { Min. }=0 \\
\text { Max. }=100\end{array}$ \\
\hline Social benefits & $\begin{array}{l}\text { Education is important to } \\
\text { be "someone" in life. }\end{array}$ & $\begin{array}{l}\text { not at all true }=1 \\
{[\ldots]} \\
\text { completely true }=6\end{array}$ & $\begin{array}{l}1=0.68 \% \\
2=0.46 \% \\
3=1.35 \% \\
4=2.94 \% \\
5=15.65 \% \\
6=78.91 \%\end{array}$ \\
\hline Relative risk aversion & $\begin{array}{l}\text { How much would it bother } \\
\text { your parents if you ended } \\
\text { up in a less prestigious } \\
\text { profession than theirs? }\end{array}$ & $\begin{array}{l}\text { not at all = } 1 \\
{[\ldots]} \\
\text { a lot }=5\end{array}$ & $\begin{array}{l}1=34.61 \% \\
2=14.70 \% \\
3=14.03 \% \\
4=22.86 \% \\
5=13.81 \%\end{array}$ \\
\hline $\begin{array}{l}\text { Individual risk } \\
\text { aversion }\end{array}$ & $\begin{array}{l}\text { Choice situation: As a } \\
\text { reward for your } \\
\text { participation we would } \\
\text { now like to give you a gift. } \\
\text { You can choose between } 2 \\
\text { options: (1) You get a } \\
\text { candy or (2) you enter a }\end{array}$ & $\begin{array}{l}\text { No participation = } 1 \text { (risk } \\
\text { averse) } \\
\text { Participation = } 0 \text { (risk seeking) }\end{array}$ & $\begin{array}{l}0=46.70 \% \\
1=53.30 \%\end{array}$ \\
\hline
\end{tabular}




\begin{tabular}{|c|c|c|c|}
\hline & $\begin{array}{l}\text { lottery for } 12 \text { candies } \\
\text { where, on average, one out } \\
\text { of three persons will win. } \\
\text { What is your choice? }\end{array}$ & & \\
\hline Time discounting & $\begin{array}{l}\text { Choice situation: You can } \\
\text { now participate in a (real!) } \\
\text { lottery. Among all } \\
\text { participants, we will } \\
\text { randomly select one } \\
\text { winner. If you win you have } \\
\text { two choices: (1) You get } 10 \\
\text { USD immediately or (2) you } \\
\text { get } 100 \text { USD in a year. } \\
\text { What is your choice? }\end{array}$ & $\begin{array}{l}\text { Choice } 1 \text { = } 1 \text { (higher time } \\
\text { discounting) } \\
\text { Choice } 2=0 \text { (lower time } \\
\text { discounting) }\end{array}$ & $\begin{array}{l}0=30.08 \% \\
1=69.92 \%\end{array}$ \\
\hline \multicolumn{4}{|l|}{ Control variables } \\
\hline Gender & What is your sex? & $\begin{array}{l}\text { male }=0 \\
\text { female }=1\end{array}$ & $\begin{array}{l}0=46.95 \% \\
1=53.05 \%\end{array}$ \\
\hline Age & How old are you? & (in years) & $\begin{array}{l}\text { Mean }=18.28 \\
\text { Std. Dev. }=0.097 \\
\text { Median }=18 \\
\text { Min }=16 \\
\text { Max }=37\end{array}$ \\
\hline Children & $\begin{array}{l}\text { Do you have children? Are } \\
\text { you pregnant? }\end{array}$ & $\begin{array}{l}\text { no }=0 \\
\text { yes }=1\end{array}$ & $\begin{array}{l}0=90.07 \% \\
1=9.93 \%\end{array}$ \\
\hline $\begin{array}{l}\text { Type of high school } \\
\text { attended }\end{array}$ & [stratification variable] & $\begin{array}{l}\text { general = } 1 \\
\text { technical = } 2 \\
\text { weekend = } 3\end{array}$ & $\begin{array}{l}1=40.41 \% \\
2=44.47 \% \\
3=15.12 \%\end{array}$ \\
\hline $\begin{array}{l}\text { Municipalities with } \\
\text { entry examinations }\end{array}$ & $\begin{array}{l}\text { based on stratification } \\
\text { variable }\end{array}$ & $\begin{array}{l}0=\text { no examination } \\
1=\text { examinations }\end{array}$ & $\begin{array}{l}0=90.96 \% \\
1=9.04 \%\end{array}$ \\
\hline Zone & [stratification variable] & $\begin{array}{l}\text { urban }=1 \\
\text { semi-urban = } 2 \\
\text { rural = } 3\end{array}$ & $\begin{array}{l}1=17.92 \% \\
2=43.32 \% \\
3=38.77 \%\end{array}$ \\
\hline Region & [stratification variable] & $\begin{array}{l}\text { North }=1 \\
\text { Center }=2 \\
\text { South }=3\end{array}$ & $\begin{array}{l}1=36.57 \% \\
2=19.41 \% \\
3=44.02 \%\end{array}$ \\
\hline
\end{tabular}


Table A2: Bivariate correlations between parental social background and cost-benefit variables

\begin{tabular}{|c|c|c|c|c|c|c|}
\hline & \multicolumn{2}{|c|}{ Parental education } & \multirow[b]{2}{*}{$\begin{array}{l}\text { Difference } \\
\text { (p-value) }\end{array}$} & \multicolumn{2}{|c|}{ Parental social class } & \multirow[b]{2}{*}{$\begin{array}{c}\text { Difference } \\
\text { (p-value) }\end{array}$} \\
\hline & $\begin{array}{l}\text { no educ. } \\
\text { degree }\end{array}$ & $\begin{array}{c}\text { some educ. } \\
\text { degree }\end{array}$ & & $\begin{array}{l}\text { social } \\
\text { class <= } \\
\text { median }\end{array}$ & $\begin{array}{l}\text { social } \\
\text { class }> \\
\text { median }\end{array}$ & \\
\hline $\begin{array}{l}\text { Direct Costs } \\
\text { (Estimated Expenditures) }\end{array}$ & $\begin{array}{l}21.714 \\
1.216\end{array}$ & $\begin{array}{l}22.982 \\
1.160\end{array}$ & $\begin{array}{l}-1.267 \\
0.313\end{array}$ & $\begin{array}{l}22.260 \\
0.902\end{array}$ & $\begin{array}{l}22.675 \\
1.593\end{array}$ & $\begin{array}{l}-0.415 \\
0.797\end{array}$ \\
\hline $\begin{array}{l}\text { Indirect Costs } \\
\text { (Estimated Forgone Earnings) }\end{array}$ & $\begin{array}{l}8.516 \\
0.846\end{array}$ & $\begin{array}{l}7.571 \\
0.360\end{array}$ & $\begin{array}{l}0.945 \\
0.296\end{array}$ & $\begin{array}{l}8.005 \\
0.804\end{array}$ & $\begin{array}{l}7.899 \\
0.386\end{array}$ & $\begin{array}{l}0.106 \\
0.911\end{array}$ \\
\hline $\begin{array}{l}\text { Burden of Direct Costs I } \\
\text { (Affordability University) }\end{array}$ & $\begin{array}{l}0.728 \\
0.043\end{array}$ & $\begin{array}{l}0.338 \\
0.039\end{array}$ & $\begin{array}{l}0.390 \\
0.000\end{array}$ & $\begin{array}{l}0.686 \\
0.040\end{array}$ & $\begin{array}{l}0.311 \\
0.051\end{array}$ & $\begin{array}{l}0.375 \\
0.000\end{array}$ \\
\hline $\begin{array}{l}\text { Burden of Direct Costs II } \\
\text { (Economic Challenge) }\end{array}$ & $\begin{array}{l}4.043 \\
0.076\end{array}$ & $\begin{array}{l}4.764 \\
0.076\end{array}$ & $\begin{array}{l}-0.721 \\
0.000\end{array}$ & $\begin{array}{l}4.104 \\
0.091\end{array}$ & $\begin{array}{l}4.832 \\
0.066\end{array}$ & $\begin{array}{l}-0.728 \\
0.000\end{array}$ \\
\hline $\begin{array}{l}\text { Burden of Indirect Costs } \\
\text { (Need to Support Family) }\end{array}$ & $\begin{array}{l}4.171 \\
0.107\end{array}$ & $\begin{array}{l}4.489 \\
0.117\end{array}$ & $\begin{array}{l}-0.318 \\
0.075\end{array}$ & $\begin{array}{l}4.144 \\
0.127\end{array}$ & $\begin{array}{l}4.571 \\
0.072\end{array}$ & $\begin{array}{l}-0.428 \\
0.011\end{array}$ \\
\hline $\begin{array}{l}\text { Subjective Success Probability } \\
\text { (Academic Confidence) }\end{array}$ & $\begin{array}{l}5.347 \\
0.069\end{array}$ & $\begin{array}{l}5.235 \\
0.055\end{array}$ & $\begin{array}{l}0.111 \\
0.224\end{array}$ & $\begin{array}{l}5.347 \\
0.053\end{array}$ & $\begin{array}{l}5.215 \\
0.066\end{array}$ & $\begin{array}{l}0.132 \\
0.140\end{array}$ \\
\hline $\begin{array}{l}\text { Objective Success Probability } \\
\text { (Grades) }\end{array}$ & $\begin{array}{l}0.023 \\
0.038\end{array}$ & $\begin{array}{l}-0.015 \\
0.026\end{array}$ & $\begin{array}{l}0.038 \\
0.568\end{array}$ & $\begin{array}{l}0.055 \\
0.049\end{array}$ & $\begin{array}{l}-0.053 \\
0.048\end{array}$ & $\begin{array}{l}0.107 \\
0.294\end{array}$ \\
\hline $\begin{array}{l}\text { Economic Benefits } \\
\text { (Estim. Returns of Tert. Educ.) }\end{array}$ & $\begin{array}{l}18.679 \\
1.939\end{array}$ & $\begin{array}{l}17.424 \\
1.225\end{array}$ & $\begin{array}{l}1.255 \\
0.629\end{array}$ & $\begin{array}{l}17.311 \\
1.297\end{array}$ & $\begin{array}{l}18.525 \\
1.047\end{array}$ & $\begin{array}{l}-1.214 \\
0.387\end{array}$ \\
\hline $\begin{array}{l}\text { Social Benefits } \\
\text { (Estimated Returns Status) }\end{array}$ & $\begin{array}{l}5.583 \\
0.116\end{array}$ & $\begin{array}{l}5.737 \\
0.053\end{array}$ & $\begin{array}{l}-0.154 \\
0.263\end{array}$ & $\begin{array}{l}5.601 \\
0.107\end{array}$ & $\begin{array}{l}5.746 \\
0.041\end{array}$ & $\begin{array}{l}-0.145 \\
0.238\end{array}$ \\
\hline Status Maintenance Parents & $\begin{array}{l}2.762 \\
0.055\end{array}$ & $\begin{array}{l}2.611 \\
0.148\end{array}$ & $\begin{array}{l}0.151 \\
0.381\end{array}$ & $\begin{array}{l}2.712 \\
0.053\end{array}$ & $\begin{array}{l}2.633 \\
0.170\end{array}$ & $\begin{array}{l}0.079 \\
0.665\end{array}$ \\
\hline Risk Averse Individual & $\begin{array}{l}0.502 \\
0.066\end{array}$ & $\begin{array}{l}0.563 \\
0.067\end{array}$ & $\begin{array}{l}-0.061 \\
0.340\end{array}$ & $\begin{array}{l}0.521 \\
0.064\end{array}$ & $\begin{array}{l}0.556 \\
0.065\end{array}$ & $\begin{array}{l}-0.036 \\
0.501\end{array}$ \\
\hline High Time Discounting & $\begin{array}{l}0.631 \\
0.056\end{array}$ & $\begin{array}{l}0.731 \\
0.033\end{array}$ & $\begin{array}{l}-0.099 \\
0.037\end{array}$ & $\begin{array}{l}0.678 \\
0.044\end{array}$ & $\begin{array}{l}0.703 \\
0.050\end{array}$ & $\begin{array}{c}-0.026 \\
0.629\end{array}$ \\
\hline
\end{tabular}

Coefficients of a bivariate regressions based on imputed dataset. We present the mean and the standard deviation (the latter in brackets) as well as the differences with p-values (the latter in brackets). 
Table A3: Detailed Blinder-Oaxaca decomposition

\begin{tabular}{|c|c|c|c|c|c|}
\hline \multirow[b]{2}{*}{ Social Background: } & & \multicolumn{2}{|c|}{ Students' study aspiration } & \multicolumn{2}{|c|}{ Students' study plans } \\
\hline & & Education & Social class & Education & Social class \\
\hline \multicolumn{6}{|l|}{ Overall } \\
\hline \multirow[t]{2}{*}{ Higher soc. back. } & & $0.784^{* * *}$ & $0.752^{* * *}$ & $0.677^{* * *}$ & $0.590 * * *$ \\
\hline & & $(0.029)$ & $(0.026)$ & $(0.046)$ & $(0.044)$ \\
\hline \multirow{2}{*}{\multicolumn{2}{|c|}{ Lower soc. back. }} & $0.737^{* * *}$ & $0.760 * * *$ & $0.300 * * *$ & $0.317 * * *$ \\
\hline & & $(0.030)$ & $(0.034)$ & $(0.026)$ & $(0.030)$ \\
\hline \multirow[t]{2}{*}{ Difference } & & 0.047 & -0.008 & $0.377^{* * *}$ & $0.273^{* * *}$ \\
\hline & & $(0.034)$ & $(0.044)$ & $(0.052)$ & $(0.048)$ \\
\hline \multirow[t]{2}{*}{ Explained } & & -0.022 & 0.026 & $0.261^{* * *}$ & $0.267^{* * *}$ \\
\hline & & $(0.033)$ & $(0.020)$ & $(0.054)$ & $(0.045)$ \\
\hline \multirow[t]{2}{*}{ Unexplained } & & 0.069 & -0.034 & $0.116^{*}$ & 0.005 \\
\hline & & $(0.039)$ & $(0.042)$ & $(0.051)$ & $(0.032)$ \\
\hline \multicolumn{6}{|l|}{ Explained } \\
\hline \multirow[t]{2}{*}{ Grades } & Grades & 0.001 & 0.001 & 0.001 & 0.002 \\
\hline & & $(0.001)$ & $(0.002)$ & $(0.002)$ & $(0.004)$ \\
\hline \multirow[t]{10}{*}{ Costs } & Direct Costs & 0.003 & 0.001 & 0.003 & 0.001 \\
\hline & (Estimated Expenditures) & $(0.003)$ & $(0.004)$ & $(0.004)$ & $(0.003)$ \\
\hline & Indirect Costs & -0.003 & 0.000 & -0.003 & -0.000 \\
\hline & (Estimated Forgone Earnings) & $(0.004)$ & $(0.003)$ & $(0.004)$ & $(0.003)$ \\
\hline & Burden of Direct Costs I & 0.003 & 0.003 & $0.152 * * *$ & $0.140 * * *$ \\
\hline & (Affordability University) & $(0.022)$ & $(0.023)$ & $(0.029)$ & $(0.029)$ \\
\hline & Burden of Direct Costs II & -0.040 & $-0.044^{*}$ & -0.011 & -0.010 \\
\hline & (Economic challenge) & $(0.030)$ & $(0.015)$ & $(0.020)$ & (0.019) \\
\hline & Burden of Indirect Costs & 0.009 & 0.013 & 0.007 & 0.009 \\
\hline & (Need to Support Family) & $(0.010)$ & $(0.008)$ & $(0.006)$ & $(0.006)$ \\
\hline \multirow[t]{2}{*}{ Success } & Subjective Success Prob. & 0.014 & 0.018 & 0.010 & 0.012 \\
\hline & (Academic Confidence) & $(0.018)$ & $(0.012)$ & (0.009) & $(0.008)$ \\
\hline \multirow[t]{6}{*}{ Utility } & Economic Benefits & 0.003 & -0.002 & 0.005 & -0.004 \\
\hline & (Estimated Returns of Tertiary E.) & $(0.006)$ & $(0.003)$ & (0.009) & $(0.005)$ \\
\hline & Social Benefits & -0.006 & -0.005 & 0.000 & 0.000 \\
\hline & (Estimated Returns Status) & $(0.007)$ & $(0.006)$ & $(0.006)$ & $(0.005)$ \\
\hline & Status Maintenance Parents & 0.000 & 0.000 & 0.008 & 0.004 \\
\hline & & $(0.002)$ & $(0.001)$ & $(0.007)$ & $(0.007)$ \\
\hline \multirow[t]{4}{*}{ Psycholog. factors } & Risk Averse Individual & -0.001 & -0.000 & 0.001 & 0.001 \\
\hline & & $(0.002)$ & $(0.001)$ & $(0.002)$ & $(0.002)$ \\
\hline & High Time Discount & 0.001 & 0.000 & 0.012 & 0.002 \\
\hline & & $(0.004)$ & $(0.001)$ & $(0.007)$ & $(0.006)$ \\
\hline \multirow[t]{8}{*}{ Controls } & Age & 0.033 & $0.032^{*}$ & 0.049 & 0.042 \\
\hline & & $(0.027)$ & $(0.013)$ & $(0.031)$ & $(0.026)$ \\
\hline & Female & -0.005 & -0.001 & -0.004 & -0.002 \\
\hline & & $(0.007)$ & $(0.003)$ & $(0.007)$ & $(0.003)$ \\
\hline & Has Children & 0.006 & 0.003 & 0.006 & 0.003 \\
\hline & & $(0.006)$ & $(0.003)$ & $(0.006)$ & $(0.003)$ \\
\hline & Examination & 0.001 & 0.001 & 0.002 & 0.001 \\
\hline & & $(0.005)$ & $(0.002)$ & $(0.004)$ & $(0.002)$ \\
\hline
\end{tabular}




\begin{tabular}{|c|c|c|c|c|c|}
\hline \multirow{2}{*}{\multicolumn{2}{|c|}{ Region }} & -0.013 & -0.012 & 0.015 & 0.012 \\
\hline & & $(0.015)$ & $(0.012)$ & $(0.011)$ & (0.010) \\
\hline \multirow{2}{*}{\multicolumn{2}{|c|}{ Urbanity }} & -0.012 & -0.012 & 0.006 & 0.005 \\
\hline & & $(0.012)$ & $(0.010)$ & $(0.007)$ & $(0.007)$ \\
\hline \multirow{2}{*}{\multicolumn{2}{|c|}{ Other soc. background var. }} & -0.015 & 0.030 & 0.003 & $0.048+$ \\
\hline & & $(0.024)$ & $(0.017)$ & $(0.017)$ & $(0.023)$ \\
\hline
\end{tabular}

Two-fold decomposition using pooled model

Standard error in parentheses, ${ }^{+} p<0.1,{ }^{*} p<0.05,{ }^{* *} p<0.01,{ }^{* * *} p<0.001$

Logit coefficients reported

Education: Low social background = parents do not have an educational degree. High social background = parents have at least an elementary degree

Social Class: Low social background = Below median. High social background = Above median

Always additionally controlled for the other social background variable 